\title{
Vitamin D signaling and melanoma: role of vitamin D and its receptors in melanoma progression and management
}

\author{
Andrzej T Slominski 1,2,3, Anna A Brożyna ${ }^{4,5}$, Michal A Zmijewski ${ }^{6}$, Wojciech Jóźwicki ${ }^{4,5}$, Anton M Jetten7, \\ Rebecca S Mason ${ }^{8}$, Robert C Tuckey ${ }^{9}$ and Craig A Elmets ${ }^{1,2}$
}

Ultraviolet B (UVB), in addition to having carcinogenic activity, is required for the production of vitamin D3 (D3) in the skin which supplies $>90 \%$ of the body's requirement. Vitamin $D$ is activated through hydroxylation by 25 -hydroxylases (CYP2R1 or CYP27A1) and 1a-hydroxylase (CYP27B1) to produce $1,25(\mathrm{OH})_{2} \mathrm{D} 3$, or through the action of CYP11A1 to produce mono-di- and trihydroxy-D3 products that can be further modified by CYP27B1, CYP27A1, and CYP24A1. The active forms of D3, in addition to regulating calcium metabolism, exert pleiotropic activities, which include anticarcinogenic and anti-melanoma effects in experimental models, with photoprotection against UVB-induced damage. These diverse effects are mediated through an interaction with the vitamin D receptor (VDR) and/or as most recently demonstrated through action on retinoic acid orphan receptors (ROR)a and RORY. With respect to melanoma, low levels of $25(\mathrm{OH}) \mathrm{D}$ are associated with thicker tumors and reduced patient survival. Furthermore, single-nucleotide polymorphisms of VDR and the vitamin D-binding protein (VDP) genes affect melanomagenesis or disease outcome. Clinicopathological analyses have shown positive correlation between low or undetectable expression of VDR and/or CYP27B1 in melanoma with tumor progression and shorter overall (OS) and disease-free survival (DFS) times. Paradoxically, this correlation was reversed for CYP24A1 (inactivating 24-hydroxylase), indicating that this enzyme, while inactivating 1,25(OH) 2 D3, can activate other forms of D3 that are products of the non-canonical pathway initiated by CYP11A1. An inverse correlation has been found between the levels of RORa and RORy expression and melanoma progression and disease outcome. Therefore, we propose that defects in vitamin D signaling including D3 activation/inactivation, and the expression and activity of the corresponding receptors, affect melanoma progression and the outcome of the disease. The existence of multiple bioactive forms of D3 and alternative receptors affecting the behavior of melanoma should be taken into consideration when applying vitamin D management for melanoma therapy.

Laboratory Investigation (2017) 97, 706-724; doi:10.1038/labinvest.2017.3; published online 20 February 2017

\section{VITAMIN D IN A 'NUTSHELL' Cutaneous Vitamin D Formation and the Relationship with Skin and UV-Radiation}

Ultraviolet radiation (UVR) with its highly energetic UVB wavelengths $(\lambda=280-320 \mathrm{~nm})$ represents a major risk factor for all forms of skin cancer including malignant melanoma (Figure 1). ${ }^{1}$ The same spectrum of solar radiation, UVB, is necessary for vitamin $\mathrm{D}$ production in the skin, which supplies $>90 \%$ of the body's requirement for this prohormone. ${ }^{2-4}$ The UVB energy is absorbed by the unsaturated-B ring of 7-dehydrocholesterol (7DHC) in the epidermis, which leads to its photochemical transformation to vitamin D3 (D3) or, depending on the UVB dose, to lumisterol and tachysterol (Figure 1). ${ }^{5}$ These 'over-irradiation' products have no known classical vitamin D activity, but may contribute to protection from UV-induced DNA

\footnotetext{
'Department of Dermatology, University of Alabama at Birmingham, Birmingham, AL, USA; ${ }^{2}$ Comprehensive Cancer Center, Cancer Chemoprevention Program, and Nutrition Obesity Research Center, University of Alabama at Birmingham, Birmingham, AL, USA; ${ }^{3}$ Pathology and Laboratory Medicine, VA Medical Center, Birmingham, AL, USA; ${ }^{4}$ Department of Tumor Pathology and Pathomorphology, Oncology Centre - Prof. Franciszek Łukaszczyk Memorial Hospital, Bydgoszcz, Poland; ${ }^{5}$ Department of Tumor Pathology and Pathomorphology, Faculty of Health Sciences, Nicolaus Copernicus University Collegium Medicum in Bydgoszcz, Bydgoszcz, Poland; ${ }^{6}$ Department of Histology, Medical University of Gdańsk, Poland; ${ }^{7}$ Immunity, Inflammation and Disease Laboratory, National Institute of Environmental Health Sciences, National Institutes of Health, Research Triangle Park, NC, USA; ${ }^{8}$ Bosch Institute and School of Medical Sciences, Sydney Medical School, The University of Sydney, Sydney, Australia and ${ }^{9}$ School of Chemistry and Biochemistry, The University of Western Australia, Crawley, Perth, WA, Australia

Correspondence: Professor A Slominski, MD, PhD, Department of Dermatology, University of Alabama at Birmingham, Birmingham, AL 35294-0009, USA.

E-mail: aslominski@uabmc.edu
}

Received 12 August 2016; revised 22 December 2016; accepted 23 December 2016 


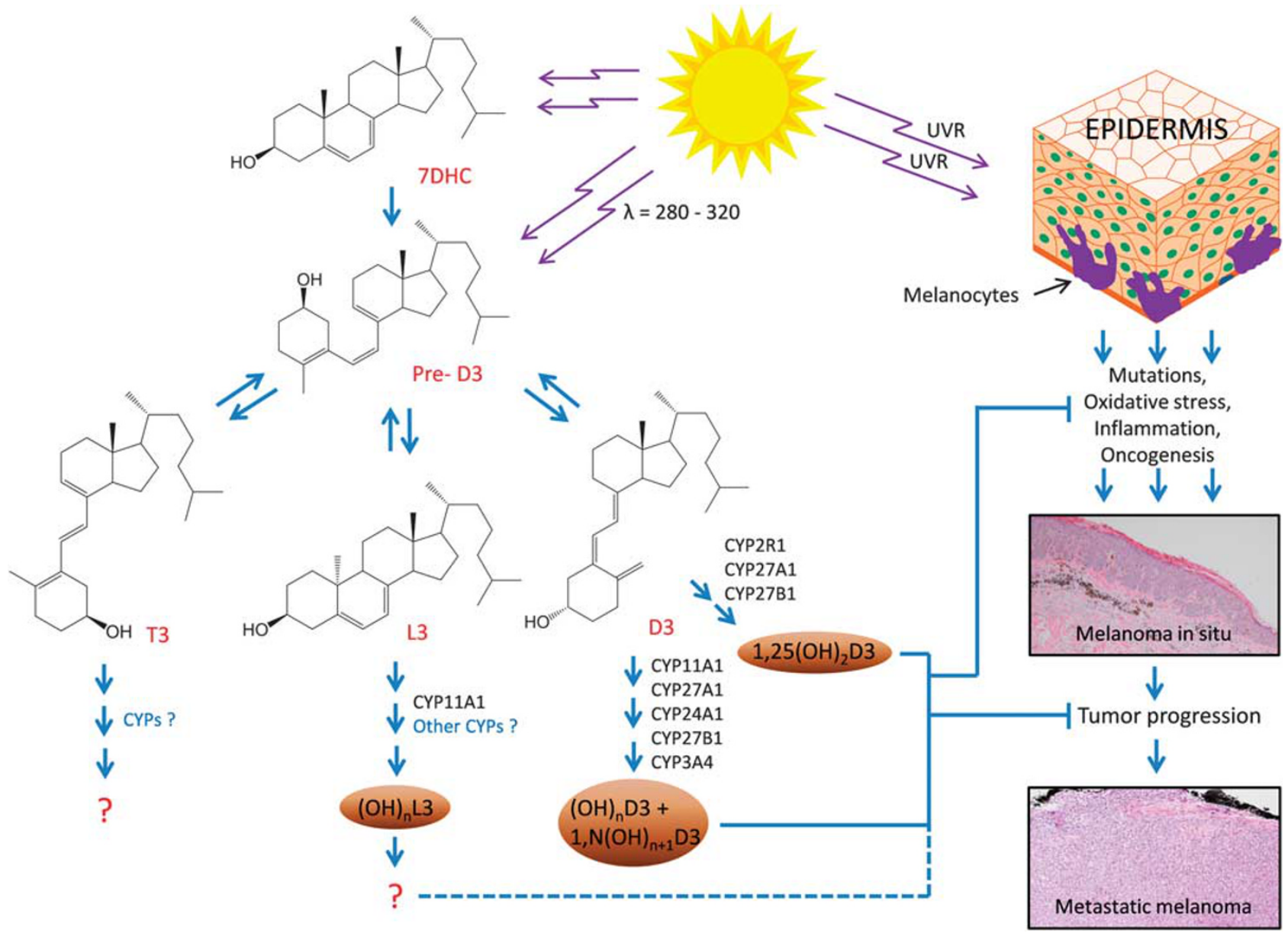

Figure 1 Ultraviolet B as a double-edged sword. UVR promotes melanomagenesis and tumor progression. However, UVB is necessary for vitamin D formation, which after activation by CYP enzymes can attenuate carcinogenesis, tumor progression and tumor growth. It is possible that hydroxylumisterols may also have similar activity as indicated by our cell culture studies (not shown). UVB, ultraviolet B; UVR, ultraviolet radiation.

damage. ${ }^{6,7}$ The ability of UV to raise vitamin D status is determined by factors such as amounts of sun exposure and timing of that exposure, ${ }^{6,7}$ skin surface area exposed, ${ }^{7}$ and skin type including pigmentation level. ${ }^{7,8}$

\section{How and Where the Biosynthesis of Active Forms of Vitamin D Takes Place}

The liver and kidney are the major organs where the activation of D3 occurs, with liver 25-hydroxylases (CYP2R1 or CYP27A1) producing $25(\mathrm{OH}) \mathrm{D} 3$ and kidney $1 \alpha$-hydroxylase (CYP27B1) converting this to 1,25-diydroxyvitamin D3 $\left(1,25(\mathrm{OH})_{2} \mathrm{D} 3\right)$ (Figure 1). $)^{2,3,9,10}$ Vitamin $\mathrm{D}$ activating enzymes are also present in extra-hepatic and extra-renal sites, including skin, so D3 can be fully activated in the epidermis. ${ }^{2,11-14} 1,25(\mathrm{OH})_{2} \mathrm{D} 3$ (calcitriol) is inactivated by CYP24A1, which initially hydroxylates at C24 then further oxidizes the side chain to produce calcitroic acid. ${ }^{15-18}$ It carries out similar reactions on $25(\mathrm{OH}) \mathrm{D} 3$.

7DHC, the precursor to vitamin D3, is the last intermediate in cholesterol biosynthesis via the Kandutsch-Russel pathway and is UV-sensitive due to the two double bonds in the B-ring. ${ }^{19}$ Although it had been suggested that statin drugs used for treatment of hypercholesterolemia patients may also decrease the incidence of melanoma, ${ }^{20}$ clinical analyses do not substantiate the above hypothesis. ${ }^{21,22}$ Thus the described anti-melanoma activity in vitro ${ }^{23,24}$ may simply represent a cell culture phenomenon without a translation into clinical reality. However, it is interesting that while a decrease in 7DHC resulting from the inhibition of the cholesterol biosynthesis might be predicted to reduce vitamin $\mathrm{D}$ synthesis in the skin, the reverse has been found, $25(\mathrm{OH}) \mathrm{D} 3$ and 1,25 $(\mathrm{OH})_{2} \mathrm{D} 3$ levels are increased with statin treatment. ${ }^{25,26}$ The mechanism underlying these observations is unclear.

\section{Importance of Vitamin D in Biology, Including Cancer}

The most clearly established effects of vitamin D are to help maintain calcium and phosphate homeostasis, and to optimize bone health and muscle function. ${ }^{27,28}$ The hormonal form, $1,25(\mathrm{OH})_{2} \mathrm{D}$, increases active intestinal calcium (and phosphate) absorption, which helps offset obligatory calcium 
losses from kidneys, gut, and skin. Severe vitamin D deficiency impairs bone mineralization, resulting in rickets (in children) and osteomalacia in adults. Vitamin D deficiency is an independent predictor of falls in the elderly, and circulating 25OHD3 levels $<60-75 \mathrm{nmol} / \mathrm{l}$ have been associated with lower extremity muscle weakness and impaired balance, and accelerated losses in muscle mass, strength, and physical function. ${ }^{28}$ Several meta-analyses report that giving vitamin $\mathrm{D}$, usually with calcium, to vitamin $\mathrm{D}$ deficient individuals reduces falls, fractures and overall mortality. ${ }^{29-33}$ Associations between vitamin D deficiency and poor outcomes of a variety of diseases including various types of malignancies (eg, colon-, skin-, and breast cancer), autoimmune diseases, infectious diseases, and cardiovascular diseases have been generally reported in a large number of studies. ${ }^{3,34}$

\section{Novel Pathways of Vitamin D Activation}

Alternative pathways of vitamin D activation have been described recently. ${ }^{19}$ They are initiated by the action of CYP11A1 on the side chain of vitamin D with the preferred initial site of hydroxylation being at $\mathrm{C} 20$. The major pathways are: $\quad \mathrm{D} 3 \rightarrow 20(\mathrm{OH}) \mathrm{D} 3+22(\mathrm{OH}) \mathrm{D} 3+17(\mathrm{OH}) \mathrm{D} 3 \rightarrow(\mathrm{OH}) \mathrm{nD} 3$ and $\mathrm{D} 2 \rightarrow 20(\mathrm{OH}) \mathrm{D} 2 \rightarrow 17,20(\mathrm{OH})_{2} \mathrm{D} 2 \rightarrow 17,20,24(\mathrm{OH})_{3} \mathrm{D} 2+$ $1,20(\mathrm{OH})_{2} \mathrm{D} 2 .{ }^{35-47} \mathrm{CYP} 11 \mathrm{~A} 1$ is the rate-limiting enzyme of steroidogenesis, where its role is the conversion of cholesterol to pregnenolone. ${ }^{48,49} 20(\mathrm{OH}) \mathrm{D} 3$ and other intermediates of the pathway can be further hydroxylated by CYP27A1, CYP24A1, CYP3A4, and CYP27B1, producing potentially more than 21 hydroxymetabolites (reviewed in refs 19,50). Many of these, including 20(OH)D3 and $22(\mathrm{OH}) \mathrm{D} 3$, are produced in tissues expressing CYP11A1 (Figure 1), and they are present in human epidermis and serum. ${ }^{44,51,52}$ They are also biologically active (reviewed in refs $50,53,54$ ).

In addition, CYP11A1 can hydroxylate 7DHC (pro-vitamin D3) at C22 and C20 and then catalyze the oxidative cleavage of the bond between $\mathrm{C} 20$ and $\mathrm{C} 22$ to produce 7dehydropregnenolone (7DHP), ${ }^{55,56}$ which can further be hydroxylated to $\Delta 7$-steroids. ${ }^{57-61}$ Since $\Delta 7$-steroids are detectable in the serum and epidermis, ${ }^{52,57-61}$ they can potentially be transformed to the corresponding vitamin $\mathrm{D}$ analogs with a short side chain (pregnacalciferols $(\mathrm{pD})$ ) or no side chain (androgen-like $(\mathrm{aD})$ ) or their pregnalumisterol (pL) counterparts after exposure of skin to UVB. ${ }^{56,62-65}$ The $\mathrm{pD}$ and $\mathrm{aD}$ compounds are also biologically active. ${ }^{63-67}$ Moreover, CYP11A1 can metabolize lumisterol to several hydroxylumisterol (L) derivatives and $\mathrm{pL}^{68}$ (Figure 1).

\section{MECHANISM OF ACTION OF VITAMIN D}

The pleiotropic activities of active forms of vitamin $\mathrm{D}$ are mediated through interaction with the vitamin $\mathrm{D}$ receptor (VDR) also known as nuclear receptor subfamily 1 , group I, member 1 (NR1/1), ${ }^{69-76}$ a member of the nuclear receptor superfamily. ${ }^{77}$ Genomic activities of vitamin D are initiated when the VDR-ligand complex forms a heterodimer with the retinoid receptor, RXR, in the cytoplasm which then translocates to the nucleus, where it binds to vitamin D responsive elements in target genes and recruits either coactivators or corepressors to regulate transcription. ${ }^{71,72,78}$ The VDR is expressed in all organs and almost all cells of the body, where it regulates a variety of their functions in addition to the regulation of calcium metabolism. ${ }^{70,71,73}$ Approximately 3\% of the mammalian genome is regulated, directly and/or indirectly by signaling secondary to activation of the VDR. ${ }^{73}$ The VDR is also widely expressed in $\operatorname{skin}^{79}$ and regulates various functions, including barrier, secretory, adnexal and immune functions, and protecting against UVinduced damage. ${ }^{73,80-88}$ Thus the skin is not only a source of active vitamin $\mathrm{D} 3$ but is also a target of its activity.

The VDR also contains an alternative $1,25(\mathrm{OH})_{2} \mathrm{D} 3$-binding A-pocket occupation of which can induce rapid non-genomic responses at the membrane level, independent from its action as a nuclear receptor. ${ }^{76,89-91}$ Furthermore, 1,25D3-membraneassociated, rapid response steroid-binding protein $(1,25 \mathrm{D} 3-$ MARRS, PDIA3) has been identified as an alternative membrane bound receptor for active forms of D3 that can regulate some phenotypic functions. ${ }^{92,93}$ Finally, some active hydroxylated forms of D3 can act on the retinoic acid-related orphan receptors (RORs) $\alpha$ and $\gamma$ as inverse agonists. ${ }^{94-96}$ Thus, in addition to the well-established mechanism of activation by binding of active forms of vitamin $\mathrm{D}$ to the genomic site of the VDR, there are non-genomic membraneassociated sites of action (A-VDR and 1,25D3-MARRS) as well as other nuclear receptor targets comprising ROR- $\alpha$ and $-\gamma \cdot{ }^{95}$ The regulatory targets for $\mathrm{pD}$ and $\mathrm{aD}$ secosteroids or lumisterol compounds remain to be identified.

\section{ANTICARCINOGENIC PROPERTIES OF VITAMIN D: AN OVERVIEW}

Population-based studies that originally started in 1980 by Garland and Garland, ${ }^{97}$ proposed that insufficient levels of vitamin $\mathrm{D}$ in the serum increase the risk and incidence of human cancers and decreases survival. ${ }^{98-106}$ The results of epidemiological studies have been supported by animal-based reports showing an increased cancer risk in VDR-deficient animals, ${ }^{107}$ and reduced cancer incidence and tumor shrinkage when treated with vitamin D. ${ }^{9,108-110}$ Moreover, malignant cells, including melanoma, express VDR and respond to the pleiotropic activities of $1,25(\mathrm{OH})_{2} \mathrm{D} 3 .{ }^{108,111}$ Subsequently, molecular analysis identified a number of genes and signaling pathways located downstream of the VDR. ${ }^{3,4,69}$ Active forms of $\mathrm{D} 3$ can enhance superoxide dismutase (SOD) 1 and 2 activities, upregulate expression of GADD45, p53 and others, all in order to protect against oxidative DNA damages (reviewed in ref. 69). In addition, $1,25(\mathrm{OH})_{2} \mathrm{D} 3$, acting through the VDR, inhibits cell proliferation both in normal and malignant cells. ${ }^{12-115}$ Similarly, newly discovered vitamin D derivatives, such as $20(\mathrm{OH}) \mathrm{D} 3,20(\mathrm{OH}) \mathrm{D} 2,1,20$ $(\mathrm{OH})_{2} \mathrm{D} 3$, and $20,23(\mathrm{OH})_{2} \mathrm{D} 3$, show VDR-mediated antiproliferative properties comparable to those of $1,25(\mathrm{OH})_{2}$ 
D3, ${ }^{39,41,116-120}$ while, at the same time showing less calcemic effects. ${ }^{39,54,117}$

The proliferation of cells is regulated via complex, tissuedependent signaling pathways with active forms of vitamin D affecting the expression of growth factors and proteins controlling the cell cycle. Regulation of the cyclindependent kinase (CDK) inhibitors, p21 and p27, by 1,25 $(\mathrm{OH})_{2} \mathrm{D} 3$ induces cell cycle arrest. ${ }^{121-123}$ Also, active forms of vitamin D increase the expression of IGF-binding protein 3, thereby inhibiting the IGF-1- and IGF-2-stimulated cell proliferation ${ }^{124-126}$ and decreases telomerase reverse transcriptase (TERT), which leads to an attenuation of telomerase activity and cell division (reviewed in ref. 127). 1,25(OH) ${ }_{2} \mathrm{D} 3$ is important both in early and late stages of cancer development and progression regulating the expression of TGF $\beta$. By increasing the expression of TGF $\beta$, active forms of vitamin $\mathrm{D}$ enhance growth inhibition. ${ }^{128-130}$ On the other hand, $1,25(\mathrm{OH})_{2} \mathrm{D} 3$ attenuates the invasion and migration induced by TGF- $\beta 1 / \beta 2$, in addition to inhibiting the epithelial-mesenchymal transition (EMT) and inhibiting the secretion of MMP-2 and MMP-9. ${ }^{131}$ These mechanisms, and enhanced expression of E-cadherin, a well-known tumor protein suppressing the invasive phenotype of cancer cells, by vitamin $\mathrm{D}$, are able to decrease the metastatic potential of cancer cells treated with $1,25(\mathrm{OH})_{2} \mathrm{D} 3 .^{132,133}$

Active forms of vitamin $\mathrm{D}$, both in normal and malignant cells, stimulate differentiation, maturation and senescence. ${ }^{39,116,118,134,135}$ These processes are regulated by cell-specific mechanisms and involve inhibition of hedgehog, $\beta$-catenin, $\mathrm{NF} \kappa \mathrm{B}$, and $\mathrm{PI} 3 \mathrm{~K}$ signaling pathways (refs 134,136,137 reviewed in refs 127,138). Apoptosis is also regulated by vitamin D. $1,25(\mathrm{OH})_{2} \mathrm{D} 3$-induced programmed cell death is mainly due to downregulation of the antiapoptotic proteins $\mathrm{Bcl}-2$ and $\mathrm{Bcl}-\mathrm{X}_{\mathrm{L}}$, upregulation of proapoptotic BAX, GOS2, DAP-3, FADD, and caspases (reviewed in refs $69,127,139)$. In addition, to control and modulation of proliferation, apoptosis, and differentiation/maturation, a variety of other tissue functions, important in tumor initiation, development and progression, are regulated by active forms of vitamin D. Consistently, vitamin D has been shown to act as an anticancer drug by inhibiting angiogenesis. ${ }^{140,141}$ As illustrated by cell- and animal-based studies, inhibition of IL-8-mediated angiogenesis, a reduction in endothelial cell proliferation, and a downregulation of vascular endothelial growth factor (VEGF), including hypoxia-induced VEGF expression, is mediated through vitamin D. ${ }^{140,142,143}$ Autophagy represents a double-edged sword that has an essential role in cell survival, but at the same time it causes cell death when apoptotic pathways are inactive. In tumors, autophagy is activated following anticancer treatment (reviewed in ref. 144) and $1,25(\mathrm{OH})_{2} \mathrm{D} 3-$ induced death of malignant cells includes this apoptosisindependent pathway through upregulation of beclin-1 (autophagy-related gene, the mammalian ortholog of yeast Atg6 protein). Similar autophagy-related cancer cell death induction is also shown by the vitamin analog, EB1089. ${ }^{145-148}$ Vitamin D-mediated cell death by autophagy is enhanced when p19 is lost and attenuated by loss of p27. ${ }^{149}$ Detailed analysis of autophagy in cancer cells revealed that $1,25(\mathrm{OH})_{2} \mathrm{D} 3$ switches the mode of autophagy from cytoprotective to cytotoxicity, sensitizing cells to antitumor treatment. ${ }^{145,150}$ Another autophagic mediator, mTOR, can be suppressed by vitamin D-regulated mTOR inhibitors. ${ }^{151}$ These very recent discoveries concerning $1,25(\mathrm{OH})_{2} \mathrm{D} 3$ and autophagy implicate a novel potential therapeutic approach for melanoma therapy through targeting autophagy with active forms of vitamin D. ${ }^{152}$

The $1,25(\mathrm{OH})_{2} \mathrm{D} 3$-regulated anti-inflammatory effect is primarily mediated by inhibition of prostaglandin (PG) signaling. $1,25(\mathrm{OH})_{2} \mathrm{D} 3$ regulates the $\mathrm{PG}$ pathway by suppressing cyclooxygenase 2 (COX-2), by increasing expression of the catabolic enzyme 15-hydroxyprostaglandin dehydrogenase, and by reducing expression of prostaglandin receptors (reviewed in ref. 153). Promoting the expression of mitogen-activated protein kinase phosphatase-5 (MKP5), which prevents phosphorylation and activation of the stress kinase $\mathrm{p} 38$, results in attenuation of the production of proinflammatory cytokines such as IL-6. The anti-inflammatory effect of $1,25(\mathrm{OH})_{2} \mathrm{D} 3$ has been shown in normal cells. ${ }^{154}$ The nuclear factor kappa $\mathrm{B}(\mathrm{NF} \kappa \mathrm{B})$ signaling pathway is also regulated by $1,25(\mathrm{OH})_{2} \mathrm{D} 3$, and shows both pro- or antiinflammatory properties since $1,25(\mathrm{OH})_{2} \mathrm{D} 3$ regulates both the phosphorylation of the inhibitor I kappaB alpha (I $\mathrm{I} B \alpha$ ) via Akt kinase and increases I $\mathrm{KB} \alpha$ synthesis. ${ }^{155} 1,25(\mathrm{OH})_{2} \mathrm{D} 3$ inhibits $\mathrm{NF} \kappa \mathrm{B}$ signaling by preventing the translocation of the p65 subunit to the nucleus, thereby attenuating $\mathrm{NF} \kappa \mathrm{B}-$ mediated IL-8 transcriptional activity. ${ }^{143}$

Vitamin D effects on inflammation (important in cancer development) are not limited to just regulation of anti- and pro-inflammatory factors, but also involve the regulation of cells of the immune system. This regulation is complex and multidirectional (reviewed in ref. 69). The major immune cells targeted by $1,25(\mathrm{OH})_{2} \mathrm{D} 3$ are $\mathrm{T}$ helper (Th2) lymphocytes. $1,25(\mathrm{OH})_{2} \mathrm{D} 3$ downregulates Th1 cytokines, upregulates Th2 cytokines by inhibiting production of the pro-inflammatory cytokines such as IL-17, TNF, IL-1, IFN- $\gamma$, and IL-2, while at the same time promoting production of the anti-inflammatory cytokines such as IL-4 and IL-10. Immune cells that are the target for $1,25(\mathrm{OH})_{2} \mathrm{D} 3$ and essential for cancer prevention are the monocytes/ macrophages, dendritic cells, and regulatory $\mathrm{T}$ cells (Treg). Vitamin D is able to modulate the function of immune cells since both the VDR and CYP27B1 are expressed by these cells (reviewed in refs 69,156). As is mentioned above, the anticancer action of vitamin $\mathrm{D}$ is complex and multidimensional, resulting from its pleiotropic properties, and involves modulation of cancer cell function, modification of the cancer microenvironment, alteration of the immune response, and others. 


\section{VITAMIN D AND MELANOMA: CLINICAL IMPLICATIONS Relationship between UVR and Melanoma}

The relationship between sunlight exposure and melanoma is not direct, since high levels of intermittent UV exposure seem to be more related to development of melanoma in susceptible individuals rather than high continuous exposure, as seen in outdoor workers. ${ }^{157} \mathrm{UV}$ exposure produces DNA damage and immune suppression, both of which contribute to melanoma development. ${ }^{158,159}$ Inadequately repaired DNA damage produced by both UVB and UVA, along with UVinduced immune suppression are involved in the pathogenesis of melanoma, particularly on sun-exposed skin. ${ }^{160,161}$ Inadequately repaired DNA damage in melanocytes may lead to mutations or amplifications of genes involved in a variety of growth and survival pathways, such as BRAF, Kit and cyclin D1. ${ }^{162}$ Melanocytes differ from keratinocytes in that they have reduced proliferation and apparently reduced capacity to repair DNA, but may be more resistant to apoptosis, despite significant DNA damage. These biological differences may help to explain the different patterns of sun exposure associated with melanoma in comparison with squamous cell carcinoma. ${ }^{160,163}$

\section{Malignant Melanoma: An Overview}

Malignant melanoma, affecting large segments of the population with a relatively high incidence rate (estimated new cases and deaths in 2016 in the USA are 7630 and 10 130, respectively) compared with other cancers and a high mortality rate, ${ }^{164,165}$ represents a significant clinical problem. Melanoma encompasses, respectively, $6 \%$ and 3\% of all new cancer cases in the USA in 2016 for males and females, excluding non-melanoma skin cancers (NMSC) of epithelial origin. ${ }^{165}$

The most efficient methods of melanoma management involve prevention, early diagnosis and surgical excision of lesional skin when the disease is localized to the skin. ${ }^{166,167}$ An impressive advancement in new therapeutic approaches including targeting molecular pathways for advanced melanomas (stages III and IV diseases) or modulations of immune responses, have been made. ${ }^{168-173}$ Unfortunately, the utilities of these strategies are somewhat limited because of adverse effects, financial costs and inherent or acquired tumor resistance mechanisms leading to recurrent disease and death of the patient (discussed in refs 173-175). Therefore, defining new regulatory targets and compounds that are nontoxic, economical with relatively limited side effects, is needed. Examples of such targets and such compounds are linked with vitamin $\mathrm{D}$ signaling as indicated by the anticancer activity of active forms of vitamin $\mathrm{D}$ and the information listed below.

\section{Polymorphism of Vitamin D-related Genes and Melanoma}

Low levels of $25(\mathrm{OH}) \mathrm{D} 3$ or $25(\mathrm{OH}) \mathrm{D} 2$ are associated with histologically thicker tumors and reduced melanoma survival, ${ }^{176-182}$ which can also be connected with a polymorphism of the gene encoding the vitamin D-binding protein $(V D B P){ }^{183,184}$ There is also evidence that singlenucleotide polymorphisms (SNPs) of the VDR gene may affect melanomagenesis or disease outcome. ${ }^{178,182,185-189}$ The role of the VDR in melanomagenesis is further illustrated by experimental models of melanoma induction where silencing of VDR or its partner RXR resulted in development of melanocytic tumors after chemically or UVB-induced carcinogenesis. ${ }^{190-192}$ This is consistent with the fundamental role of the VDR in protection against skin carcinogenesis. ${ }^{1,72,80,82,193-196}$

Although a number of $V D R$ gene polymorphisms have been identified and some of them can modify the risk and disease outcome (reviewed in refs 197,198), the published reports present some contradictory data related to VDR polymorphisms in melanomas and their association with disease outcome. ${ }^{185,186,199,200}$ The most studied VDR polymorphisms are FokI, BsmI, TaqI, and Cdx2. In some studies the BsmI A allele was associated with improved melanoma survival but increased melanoma risk, ${ }^{185,186}$ while other reports showed reduced melanoma risk $^{178}$ or poor prognosis of patients with low serum vitamin D levels. ${ }^{104}$ Another polymorphism, the FokI T allele was associated with increased melanoma risk, ${ }^{178}$ and the TaqI ' $t$ '(C) allele with a protective role in melanoma-specific survival. ${ }^{185}$ The observed discrepancies could be in part explained by the study of Newton-Bishop et al, ${ }^{104}$ showing that the effect of specific polymorphisms on survival of melanoma patients was associated with the serum level of vitamin D. Also, although VDR SNPs rs7299460, rs3782905, rs2239182, rs12370156, rs2238140, rs7305032, rs1544410 (BsmI), and rs731236 $($ TaqI) showed a statistically significant trend $(P<0.05)$ for association with melanoma-specific survival in multivariate analysis, none of them was significantly associated with Breslow thickness, ulceration or mitotic rate. ${ }^{185}$ The authors of this study proposed that the VDR gene may influence survival from melanoma, although the mechanism by which VDR exerts its effect may not be driven by tumor aggressiveness, but influenced by the host environment. ${ }^{185}$

\section{Negative Correlation between VDR Expression and Melanoma Progression}

Since the VDR is a critical mediator of the biological action of active forms of D3 and the reduction of its expression abrogates anti-tumorigenic activity (reviewed in ref. 69), clinicopathological studies have been performed on a cohort of patients monitored by the Oncology Center in Bydgoszcz to establish a relationship between VDR expression and progression of disease in melanoma patients ${ }^{201,202}$ (see Figure 1 for an overview). VDR expression decreased in advanced cutaneous melanomas and their metastases and this decrease was associated with the vertical growth phase. The lowest and/or lack of VDR expression was associated with highest Breslow thickness, Clark level and the highest melanoma stage. Also, the ulcerated melanomas, with lack 

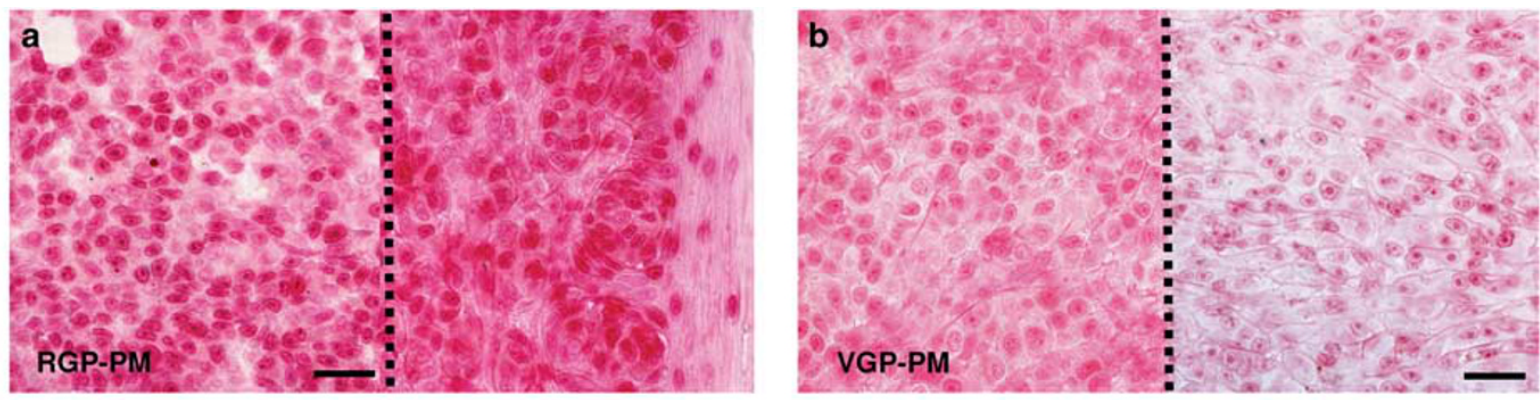

c

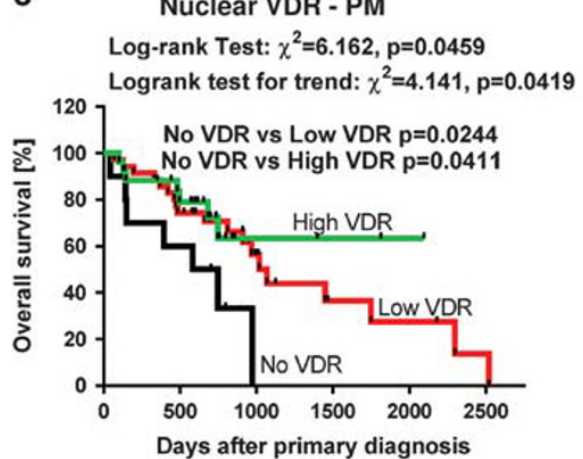

d

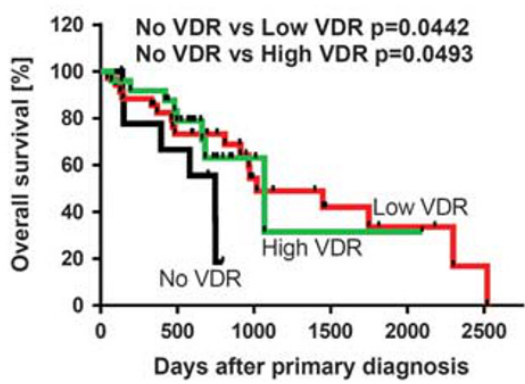

e

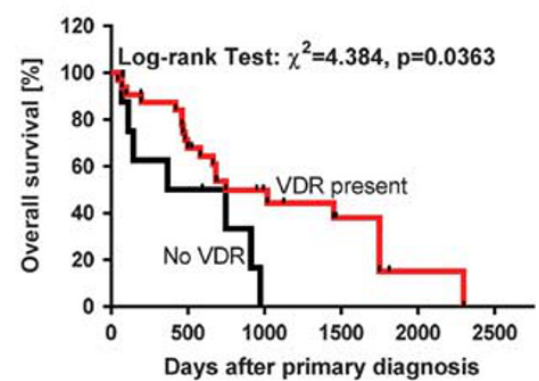

Figure 2 Correlation between VDR expression and melanoma survival. The representative VDR immunostaining in primary melanomas in RGP (a; two cases separated with dotted line) and VGP (b; two cases separated with dotted line) are shown. Dependence of OS on nuclear (c) and cytoplasmic (d) immunostaining VDR in RGP and VGP of primary melanomas, respectively, and on nuclear VDR in melanoma metastases (e). VDR-positive cells are visualized with Red AP Substrate; scale bars, $50 \mu \mathrm{m}$. The OS graphs (slightly modified) are reproduced with permission from ref. 201 (c-e). Vitamin D receptor was immunodetected with rat antibody (clone 9A7; Abcam, Cambridge, MA, USA; a dilution 1:75) and visualized with Red AP Substrate (Vector Laboratories, Burlingame, CA, USA). VDR immunostaining was scored as negative (0), weak (1), moderate (2), and strong (3), based on staining intensity. For analysis melanomas assessed as having moderate and strong VDR immunostaining were classified as high VDR, weak as low VDR, and negative as no VDR. Overall survival was calculated as the time between surgical treatment and diagnosis of primary melanoma and the time of death. Survival analysis was performed using Mantel-Cox (Log-rank) test and Log-rank test for trend. Scale bars, $50 \mu \mathrm{m}$. MM, metastatic melanomas; OS, overall survival; PM, primary melanomas; RGP, radial growth phase; VDR, vitamin D receptor; VGP, vertical growth phase.

or non-brisk tumor infiltrating lymphocytes and nodular type were characterized by lower VDR expression. Correspondingly, longer overall and disease-free survival (DFS) was accompanied by higher VDR expression both in primary and metastatic melanomas (Figure 2). ${ }^{201,202}$

As mentioned above, $\mathrm{NF} \kappa \mathrm{B}$ is an important regulator of inflammation and cancer development, ${ }^{203,204}$ including melanoma, in which it has an important role in maintaining the malignant behavior. ${ }^{205-207}$ We have shown that biologically active forms of vitamin D not only induce the VDR translocation to the nucleus and inhibit melanoma proliferation ${ }^{39}$ but also that this process is associated with the downregulation of the $\mathrm{NF} \kappa \mathrm{B}$ pathway via inhibition of the nuclear translocation of the p $65 \mathrm{NF} \kappa \mathrm{B}$ subunit, its accumulation in the cytoplasm and inhibition of $\mathrm{NF} \kappa \mathrm{B}$ binding to DNA. ${ }^{120}$ Furthermore, this process differs in nonpigmented and pigmented cells. ${ }^{120}$ Nonpigmented cultured melanoma cells and nonpigmented and slightly pigmented human cutaneous melanomas show predominantly nuclear localization of the p65 $\mathrm{NF} \kappa \mathrm{B}$ subunit compared with highly pigmented melanomas. ${ }^{120}$ Interestingly, the nonpigmented melanoma cells, showing higher nuclear VDR and $\mathrm{NF} \kappa \mathrm{B}$ expression, are more susceptible to vitamin D-mediated downregulation of $\mathrm{NF} \kappa \mathrm{B}$ activity and inhibition of proliferation than pigmented melanoma cells. ${ }^{120}$ Combined analysis of clinical melanoma samples reported in refs 120,201,202 showed positive correlation between the higher percentage of NF $\kappa \mathrm{B}$-positive melanoma cells and the higher nuclear immunostaining of VDR $(r=0.35, P=0.001)$ and percentage of the Ki-67-positive melanoma cells $(r=0.20, P=0.039)$. This suggests a complex interaction between ligand-activated nuclear anti-melanoma activity of the VDR, connected at least in part with inhibition of $\mathrm{NF} \kappa \mathrm{B}$, in a context-dependent manner. Paradoxically, less differentiated amelanotic melanoma cells expressing $\mathrm{NF} \kappa \mathrm{B}$ with higher proliferative potential are a better target for the anti-melanoma activity of vitamin D than the more differentiated melanotic cells. ${ }^{120}$ One of possible explanations for this phenomenon would be a communication between the hypoxia-inducible factor- $1 \alpha$ (HIF-1 $\alpha$ ) and VDR and $\mathrm{NF} \kappa \mathrm{B}$ signaling pathways, since induction of melanogenesis dramatically stimulates nuclear expression of HIF- $1 \alpha .{ }^{208}$ The mechanism of these interactions deserve further careful studies, since recent reports have shown a negative effect of melanin content on melanoma 

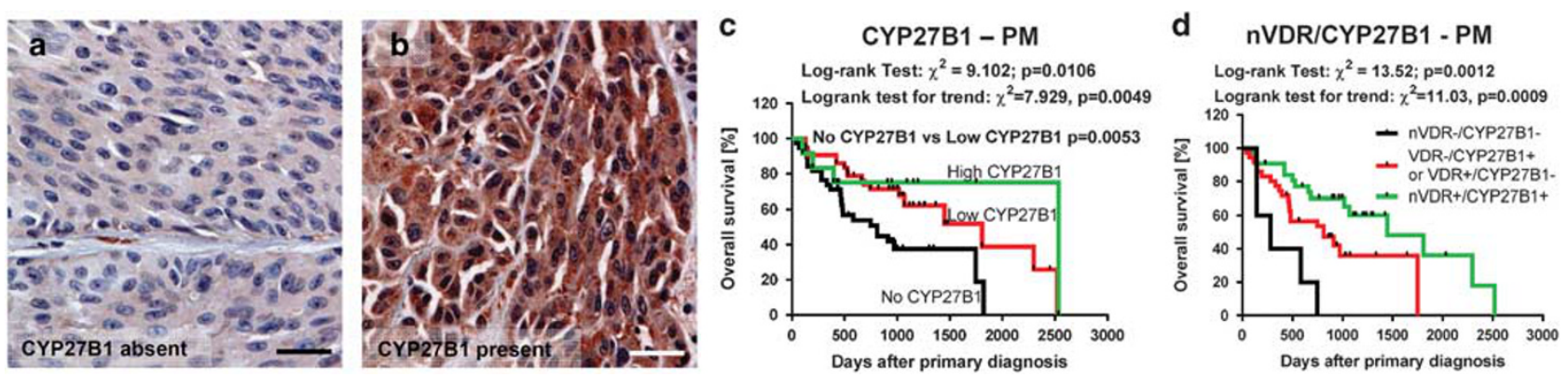

Figure 3 Correlation between CYP27B1 expression and melanoma survival. The immunostaining of melanomas classified as CYP27B1-negative (a; VGP) and CYP27B1- positive (b; RGP) are shown. Dependence of overall survival on immunostaining of CYP27B1 (c) and concomitant nuclear VDR immunostaining (nVDR) and CYP27B1 (d) in RGP of primary melanomas are also shown. The graph c (slightly modified) is reproduced with permission from ref. 223. CYP27B1 was detected with rabbit antibody (clone H-90, Santa Cruz Biotechnology, Santa Cruz, CA, USA, a dilution of 1:75) and visualized with ImmPACT NovaRED substrate (Vector Laboratories, Burlingame, CA, USA). CYP27B1 immunostaining was scored semiquantitatively, as follows: $\mathrm{SQ}=$ mean $(\mathrm{IR} \times \mathrm{SI}) / 100$, where IR represents the percentage of immunoreactive cells and $\mathrm{SI}$ is the staining intensity as negative (0), weak (1), moderate (2), or strong (3) and melanoma cases were stratified according to SQ-score as follows: no CYP27B1 =0.0-0.99, low CYP27B1 = 1.0-1.99, high CYP27B1 $=2.0-3.0$. Overall survival was calculated as time between surgical treatment and diagnosis of primary melanoma and the time of death. Survival analysis was performed using Mantel-Cox (Log-rank) test and Log-rank test for trend. nVDR immunostaining assessment was presented above and melanomas showing low or high nuclear VDR immunostaining were classified as 'nVDR+' and melanomas showing lack of VDR as ' $n V D R-$ '. Melanomas showing low or high CYP27B1 immunostaining were classified as 'CYP27B1+' and melanomas showing lack of CYP27B1 as 'CYP27B1-'. Scale bars, $50 \mu \mathrm{m}$. PM, primary melanomas; RGP, radial growth phase; VDR, vitamin D receptor; VGP, vertical growth phase.

outcome in stages III and IV disease, ${ }^{209}$ or the outcome of radiotherapy. ${ }^{210}$ This is consistent with a double-edge sword role for melanogenesis in the behavior of melanoma cells. $^{211-220}$

\section{Negative Correlation between CYP27B1 Expression and Melanoma Progression}

Besides kidney, CYP27B1 is also expressed by skin cells, ${ }^{11,12,221,222}$ including melanoma cells. ${ }^{222}$ In human cutaneous melanomas a significant reduction of CYP2B1 expression $v s$ normal skin was observed. ${ }^{223}$ The expression pattern in a variety of clinical samples of cutaneous melanomas was again similar to VDR, with the lowest CYP27B1 level being observed in more aggressive and more advanced melanomas (vertical growing melanomas, Clark levels III-V and Breslow thickness $>2.0 \mathrm{~mm}$ and metastasizing melanomas; Figure $3 \mathrm{a}$ and $\mathrm{b}$ ). Melanoma cells localized in deeper layers of skin (reticular dermis) were characterized by lower CYP27B1 expression when compared with papillary dermis. A high proliferation index and ulceration of melanomas were accompanied by a decreased CYP27B1 level. Consequently, a lack of or reduced expression of CYP27B1 in melanoma cells was associated with both shorter overall and disease-free survival of melanoma patients (Figure 3c). ${ }^{223}$ This effect was even more evident when analysis was performed for OS of patients that were both negative for nuclear VDR and negative for CYP27B1 expression (Figure 3d). The reduction of CYP27B1 expression in melanoma cells was also seen in a series ( 8 out of 11) of melanoma cell lines $v s$ both normal melanocytes and keratinocytes. ${ }^{223}$ In addition, similar to the VDR, both cultured melanoma cells and clinical samples of melanoma, showed an inverse correlation between the CYP27B1 level and high melanin content. ${ }^{223}$

\section{What is the Role of CYP24A1 in the Regulation of Melanoma Behavior?}

The best known physiological function of CYP24A1 is inactivating $1,25(\mathrm{OH})_{2} \mathrm{D} 3$ and maintaining vitamin $\mathrm{D}$ homeostasis via a negative feedback loop. ${ }^{61,119,224}$ Since elevated levels of CYP24A1 have been observed in some cancers, ${ }^{225}$ it has been proposed that inhibition of CYP24A1 activity represents a realistic molecular target for cancer therapy (reviewed in refs 69,127,226). However, this theory may not fully apply towards melanoma treatment. Specifically, CYP24A1 hydroxylates $20(\mathrm{OH}) \mathrm{D} 3)$, producing several dihydroxy-derivatives including 20,24-dihydroxyvitamin D3 (20,24 $\left.(\mathrm{OH})_{2} \mathrm{D} 3\right)$ and 20,25-dihydroxyvitamin D3 $\left(20,25(\mathrm{OH})_{2} \mathrm{D} 3\right)$ which show enhanced anti-melanoma activity in vitro. ${ }^{119}$ In addition, our studies on CYP24A1 expression in human cutaneous melanomas, showed the highest CYP24A1 levels in melanocytic nevi and early stage melanomas. ${ }^{227}$ CYP24A1 expression decreased with the melanoma progression as defined by Breslow thickness, Clark levels, pT, pN, pM, and overall stage (Figure 4a and b). ${ }^{227}$ Decreased CYP24A1 expression was also associated with poor prognostic factors including nodular type, high mitotic index, presence of ulceration, and necrosis. ${ }^{227}$ Finally, reduced CYP24A1 expression was related with shorter overall and disease-free survival of melanoma patients (Figure 4c). ${ }^{227}$ Again, melanoma patients that were positive for both CYP24A1 and nuclear VDR had significantly the best probability of survival (Figure 4d). Reduced CYP24A1 gene expression was also found in 12 out of 13 melanoma cell lines in comparison to normal melanocytes. ${ }^{227}$ It is possible that these unexpected 

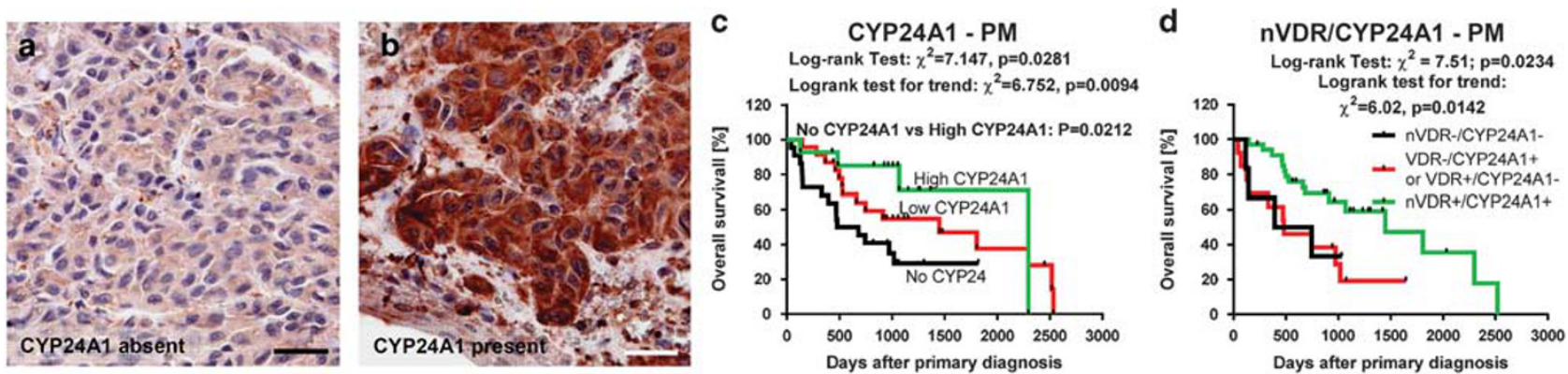

Figure 4 The relationship between CYP24A1 expression, VDR and melanoma survival. The immunostaining of melanomas classified as CYP24A1negative (a; VGP) and CYP24A1-positive (b; RGP) are shown. Dependence of overall survival on immunostaining of CYP24A1 (c) and concomitant nuclear VDR immunostaining (nVDR) and CYP24A1 (d) in RGP of primary melanomas are also shown. CYP2A1 was detected with mouse antibody (Abcam, Cambridge, UK, dilution 1:40) and visualized with ImmPACT NovaRED substrates (Vector Laboratories, Burlingame, CA, USA). CYP24A1 immunostaining was scored semiquantitatively, as follows: $S Q=$ mean $(\mathrm{IR} \times \mathrm{SI}) / 100$, where $\mathrm{IR}$ represents the percentage of immunoreactive cells and $\mathrm{SI}$ is the staining intensity as negative (0), weak (1), moderate (2) or strong (3) and melanoma patients were stratified according to the SQ-score as follows: SQ $0.0-1.0=$ no CYP24A1, SQ 1.1-2.0 = low CYP24A1, SQ 2.1-3.0= high CYP24A1. Overall survival was calculated as the time between surgical treatment and diagnosis of primary melanoma and the time of death. Survival analysis was performed using Mantel-Cox (Log-rank) test and Log-rank test for trend. nVDR immunostaining assessment was presented above and melanomas showing low or high nuclear VDR immunostaining were classified as 'nVDR+' and melanomas showing lack of VDR as 'nVDR-'. Melanomas showing low or high CYP24A1 immunostaining were classified as 'CYP24A1+' and melanomas showing lack of CYP24A1as 'CYP24A1-'. Scale bars, $50 \mu \mathrm{m}$. RGP, radial growth phase; VDR, vitamin D receptor; VGP, vertical growth phase.

findings can be explained by the recently described CYP24A1 ability to generate new potent vitamin D hydroxy derivatives with anti-melanoma activity. ${ }^{119}$ In addition, expression of CYP24A1 had, in contrast to VDR and CYP27B1, a positive correlation with melanin pigmentation both in melanoma samples and cultured melanoma cells. ${ }^{227}$ Therefore, we propose that the role of CYP24A1 in progression of melanocytic tumors may be complex, because it is involved not only in the inactivation of $1,25(\mathrm{OH})_{2} \mathrm{D} 3$, but also in the metabolism of $20(\mathrm{OH}) \mathrm{D} 3$ to its more active forms that are prone to $1 \alpha$-hydroxylation.

\section{Special Considerations on the Role of Vitamin D Signaling in Melanomagenesis and Melanoma Progression}

Both the information from the literature and our own data summarized above clearly show that the attenuation of vitamin D signaling at the local and systemic levels affects melanoma progression and the natural history of the disease including overall survival. Specifically, serum levels of $25(\mathrm{OH})$ D3, SNPs in VDR and VDBP will indicate global defects affecting both systemic and local responses aimed at cancer prevention or inhibition. In addition, loss of VDR, CYP27B1 and CYP24A1 antigens is associated with negative pathological prognostic factors and with shorter OS and DFS. Reanalysis of the data reported in refs 201,202,223,227 also showed positive correlation between nuclear expression of VDR and expression of CYP24A1 $(r=0.32, P=0.01)$, but not with CYP27B1, and positive correlation between CYP27B1 and CYP24A1 expression $(r=0.22, P=0.045)$. This is probably related to an upregulation of CYP24A1 by CYP27B1produced $1,25(\mathrm{OH})_{2} \mathrm{D} 3$ acting on the VDR. With respect to CYP27B1 and CYP24A1 SNPs, adequate information on their relationship with melanomagenesis is missing; however, it is possible as described for other tumors. ${ }^{228-230}$ Unfortunately, to the best of our knowledge there is a lack of information on the association between SNPs of CYP11A1 and melanoma, and with cancer in general. Also, there is a lack of information on alternative splicing of VDR, CYP27B1, CYP24A1, and CYP11A1 gene transcripts and the role the resulting proteins may have in melanomagenesis. It is worthy of mention that in another signaling system (corticotropin releasing hormone receptors that regulate melanogenesis and have antimelanoma activity ${ }^{231-233}$ ), alternative splicing can produce a variety of protein products with different and sometimes opposite functions. ${ }^{234-236}$ In additionally, findings that vitamin $\mathrm{D}$ signaling and its antitumor activity can be affected by melanin content are intriguing, but consistent with the hypothesis that inhibition of melanin synthesis could sensitize melanoma cells to antitumor treatment and improve survival. ${ }^{175,210,211,213}$

\section{VITAMIN D AND EXPERIMENTAL MODELS OF MELANOMA}

Anti-melanoma Activity of Classical Forms of Vitamin D In 1974, Oikawa and Nakayasu described for the first time the effects of cholecalciferol and ergocalciferol on melanoma, reporting induction of melanoma pigmentation in culture, ${ }^{237}$ an effect that could not be reproduced by other investigators (reviewed in ref. 213). However, it was Colston and colleagues, who first observed the inhibition of melanoma cell growth by $1,25(\mathrm{OH})_{2} \mathrm{D} 3$ and the presence of the VDR in cultured melanoma cells, as well as in tumor tissue. ${ }^{111}$ These two findings, confirmed by other groups, opened the door for the testing of various natural and synthetic secosteroids as potential candidates for melanoma treatment (see refs 197,238 for recent reviews). Two years after Colston's 
discovery, Frampton and collaborators, showed that two known metabolites of $1,25(\mathrm{OH})_{2} \mathrm{D} 3$, namely: $1,24,25(\mathrm{OH})$ ${ }_{3} \mathrm{D} 3$ and $1,25,26(\mathrm{OH})_{3} \mathrm{D} 3$ also effectively suppressed the proliferation of malignant melanoma MM96 cells. ${ }^{239}$ This observation was supported by the description of vitamin D metabolism in melanoma cells. ${ }^{240,241}$ Further studies showed that vitamin D inhibited the growth of several melanoma cell lines, including: human: A375, ${ }^{242} \mathrm{ME} 18,{ }^{243} \mathrm{MeWo},{ }^{244-246}$ RPMI 7951,247,248 SK Mel 28,247,249,250 SKMEL-188, WM35 and WM1341; ${ }^{39,40,64,118,119,242,251}$ mouse B16; ;7,252,253 and hamster Bomirski melanomas. ${ }^{67,118}$ Furthermore, $1,25(\mathrm{OH})_{2} \mathrm{D} 3$ inhibited anchorage-independent growth and plating efficiency of human SKMEL-188, hamster AbC1, ${ }^{39,64,118}$ and murine B16 (ref. 253) melanomas. Interestingly, Reichrath's group and many others noticed that some melanoma lines did not respond to classic vitamin D analogs. ${ }^{246,250}$ Vitamin D-resistant melanomas in some experimental conditions included human Mel-Juso, ${ }^{250}$ SK Mel 5, 246,250,254 SK Mel 25 , and IGR, ${ }^{250}$ as well as in murine melanomas $S 91,{ }^{255}$ and B16. ${ }^{256}$ For the mouse B16 melanoma cell line it should be noted that the diverse effects of $1,25(\mathrm{OH})_{2} \mathrm{D} 3$ were observed by several groups listed above and this phenomenon was linked to different experimental setups and the use of different subclones of B16 (see ref. 197 for discussion).

Although some authors reported melanoma cell-type dependent pro-apoptotic activity of $1,25(\mathrm{OH})_{2} \mathrm{D} 3,{ }^{244}$ others have failed to find such a correlation ${ }^{243}$ despite of a significant reduction in melanoma proliferation..$^{245,257}$ It has been reported that $1,25(\mathrm{OH})_{2} \mathrm{D} 3$ induces apoptosis of WM1341 melanoma, but not MeWo cells. ${ }^{244}$ Therefore, it is possible that the pro-apoptotic activity of $1,25(\mathrm{OH})_{2} \mathrm{D} 3$ depends on cell-type-specific factors as recently described in the gastric cancer cell line HGC-27 (see recent review ref. 69). Finally, $1,25(\mathrm{OH})_{2} \mathrm{D} 3$ protects normal human primary melanocytes from apoptosis. ${ }^{258}$

There is still ongoing debate concerning the influence of vitamin D on melanin production. ${ }^{213,255,259}$ An early study by Oikawa, ${ }^{237}$ was supported by reports from different laboratories, that induction of pigmentation occurred through tyrosinase activation. ${ }^{253,260}$ However, other reports concerning $1,25(\mathrm{OH})_{2} \mathrm{D} 3$ (ref. 255) as well as a studies with the vitamin D precursor $(7 \mathrm{DHC})^{237,255}$ and other vitamin D metabolites, including $25(\mathrm{OH}) \mathrm{D} 3,1(\mathrm{OH}) \mathrm{D} 3$, and $24 \mathrm{R}, 25$ $(\mathrm{OH})_{2} \mathrm{D} 3$ (ref. 253) showed no effect on pigmentation.

The major problem in treatment of malignant melanomas is the high metastatic rate and multidrug resistance. $1,25(\mathrm{OH})_{2} \mathrm{D} 3$ was found to inhibit invasiveness, cell adhesion to the extracellular matrix and type IV collagenase activity of B16 cells; however, it did not influence cell migration. ${ }^{256}$ The sensitivity of melanoma to $1,25(\mathrm{OH})_{2} \mathrm{D} 3$ seems to correlate with stimulation of expression of genes encoding enzymes that metabolize this hormone. Thus, in melanomas responding to the inhibitory effects of $1,25(\mathrm{OH})_{2} \mathrm{D} 3$, rapid overexpression of the 24-hydroxylase gene (CYP24A1) was observed, which coincided with decreased expression of the
CYP27B1 gene. ${ }^{67,246,250}$ Also, several studies indicated elevated expression of VDR in melanomas subjected to vitamin D treatment. ${ }^{67,250,261}$ This effect appeared to be cell line specific. $^{246,249}$ Taken together, the responsiveness of melanoma cells to $1,25(\mathrm{OH})_{2} \mathrm{D} 3$ strongly depends on VDR expression and its transcriptional activity as shown by Harant et al ${ }^{262}$ explaining the higher sensitivity of RPMI 7951 cells $^{247}$ to $1,25(\mathrm{OH})_{2} \mathrm{D} 3$, effects also substantiated by our studies. ${ }^{39}$

Anti-melanoma properties of natural metabolites of vitamin $\mathrm{D}$ have also been tested in animal models of melanoma. The inhibition of solid tumor growth by 1,25 $(\mathrm{OH})_{2} \mathrm{D} 3$ was observed for VDR-expressing COLO 239F cells derived from a malignant melanoma, but not for the receptor-negative RPMI 7932 melanoma cell line. ${ }^{263}$ Interestingly, while $1,25(\mathrm{OH})_{2} \mathrm{D} 3$ did not inhibit exponential tumor growth in mice inoculated with mice B16 melanoma, both spontaneous or experimental pulmonary metastasis were inhibited by $1,25(\mathrm{OH})_{2} \mathrm{D} 3 .{ }^{256}$ Also, Albert and coworkers found that $1(\mathrm{OH}) \mathrm{D} 2$ effectively decreased growth of pigmented ocular tumor in the Tyr-Tag transgenic mouse. ${ }^{264}$

\section{Anti-Melanoma Activity of New Forms of Vitamin D}

As mentioned in section "Novel Pathways of Vitamin D Activation," novel vitamin $\mathrm{D}$ hydroxy derivatives and $\mathrm{pD}$ and $\mathrm{aD}$ secosterids show antiproliferative, pro-differentiation, anticancer, anti-inflammatory and antifibrotic activities that depend on the target cell-type. ${ }^{39,57,63-66,116,117,120,135,265-271}$ Hydroxy derivatives of vitamin D3 with a full-length (8C) side chain of which the best characterized so far are $20(\mathrm{OH}) \mathrm{D} 3,20$ $(\mathrm{OH}) \mathrm{D} 2$ and $20,23(\mathrm{OH})_{2} \mathrm{D} 3$, are nontoxic and noncalcemic in rodents at pharmacological doses $(3-4 \mu \mathrm{g} / \mathrm{kg}$ (reviewed in ref. 53). Recent tests performed on mice showed a lack of calcemia by $20(\mathrm{OH}) \mathrm{D} 3$ at extremely high doses of $30-60 \mu \mathrm{g} /$ $\mathrm{kg}$ administered to mice daily, ${ }^{268,272}$ indicating its potential to be used therapeutically.

$20(\mathrm{OH}) \mathrm{D} 3,20(\mathrm{OH}) \mathrm{D} 2$ and $20,23(\mathrm{OH})_{2} \mathrm{D} 3$ were extensively tested in vitro for their activities on melanocytes and melanoma cells (reviewed in ref. 53). Specifically, they inhibited melanocyte and human and hamster melanoma proliferation, and melanoma colony formation in monolayer and soft agar (anchorage-independent growth) with a potency similar or better than $1,25(\mathrm{OH})_{2} \mathrm{D} 3$, while having no effects on melanogenesis or dendrite formation..$^{39,67,118,120,271}$ These effects on melanoma were significantly higher than those exerted by $25(\mathrm{OH}) \mathrm{D} 3$. The in vitro anti-melanoma effect of $20(\mathrm{OH}) \mathrm{D} 3$ was associated with inhibition of NFK $\beta$ activity in a human melanoma line. ${ }^{120}$ Similar anti-melanoma activities were exerted by their $1 \alpha$-hydroxy analogs. Interestingly, 1,25 $(\mathrm{OH})_{2} \mathrm{D} 3$ and $1,20(\mathrm{OH})_{2} \mathrm{D} 3$ inhibited dendrite formation in normal melanocytes, while derivatives without a $1 \alpha$-hydroxyl group had no effect on melanocyte morphology. The addition of a $1 \alpha$-hydroxyl group potentiated the antiproliferative effect against melanocytes but not melanoma cells. ${ }^{118}$ The antimelanoma effect of $20(\mathrm{OH}) \mathrm{D} 3$ was also demonstrated in 
some clones of B16 melanoma, however, with lower potency than that for $1,25(\mathrm{OH})_{2} \mathrm{D} 3{ }^{67}$

Since melanogenesis can affect behavior of normal and malignant melanocytes, ${ }^{159,208,211-214,273}$ the effect of melanogenesis on responsiveness to vitamin $\mathrm{D}$ analogs was tested. Induction of melanin pigmentation attenuated the responsiveness of human melanoma cells to 20(OH)D3 and 1,25 $(\mathrm{OH})_{2} \mathrm{D} 3$, which was associated with a decrease in VDR expression. ${ }^{120}$ This was consistent with lower expression of VDR in pigmented melanomas as measured by immunocytochemistry. ${ }^{201,202}$ However, moderate melanogenic activity amplified the anti-melanoma effect of 1,25 $(\mathrm{OH})_{2} \mathrm{D} 3$ and $20(\mathrm{OH}) \mathrm{D} 2$ in the F10 clone of B16 melanoma, with $20(\mathrm{OH}) \mathrm{D} 3$ having the opposite effect. ${ }^{67}$ Interestingly, pigmentation attenuated $1,25(\mathrm{OH})_{2} \mathrm{D} 3$-induced translocation of the VDR to the nucleus and hyperpigmentation of B16 melanoma cells was associated with a decrease in the expression of the VDR and RXR genes. ${ }^{67}$

We also performed tests on products of CYP27A1 and CYP24A1 action on $20(\mathrm{OH}) \mathrm{D} 3$, namely $20,24(\mathrm{OH})_{2} \mathrm{D} 3,20,25$ $(\mathrm{OH})_{2} \mathrm{D} 3$ and $20,26(\mathrm{OH})_{2} \mathrm{D} 3$ and their $1 \alpha$-hydroxy derivatives (products of CYP27B1 action). ${ }^{40,119}$ These secosteroids showed stronger inhibition of colony formation by human melanoma cells than the parent $20(\mathrm{OH}) \mathrm{D} 3$, with addition of a $1 \alpha$-hydroxyl group having either small stimulatory or attenuating effects. ${ }^{40,119}$ The potencies of the hydroxy derivatives of $20(\mathrm{OH}) \mathrm{D} 3$ are consistent with their docking scores predicted using the crystal structure of the ligandbinding domain of G-VDR. ${ }^{53}$ Most recently, routes of total chemical synthesis of 20(OH)D3 and some of its dihydroxyderivatives were established and the products show antimelanoma activity in in vitro assays. ${ }^{274,275}$

Although the physiological significance of short side-chain $\Delta 7$-steroids and secosteroids is still not fully understood, in vitro experiments showed that they have antiproliferative activity in several cellular models, including human leukemias, human epidermal keratinocytes and melanoma cells, ${ }^{64,67,117,238,276}$ and also display antifibrotic activity. ${ }^{66,238}$ Importantly, vitamin $\mathrm{D}$ analogs with a shorter $\mathrm{pD}$ or $\mathrm{aD}$ side chain possess proven or predicted low calcemic activity, $277-279$ confirmed further for $17,20 S(\mathrm{OH})_{2} \mathrm{pD}$ and $17,20 R(\mathrm{OH})_{2} \mathrm{pD}$ compounds. ${ }^{66}$ The anti-melanoma activities of various vitamin $\mathrm{D}$ analogs with a shortened side chain $(\mathrm{pD}$ and $\mathrm{aD}$ ) were recently reviewed. ${ }^{53,197} \mathrm{pD}$ and its precursor, 7DHP, effectively attenuated the growth of human SKMEL-188 and hamster AbC1 melanoma cell lines in soft agar. ${ }^{57,280}$ In addition, several hydroxy derivatives of secosteroids with a short side chain were produced by UVB irradiation of the corresponding 5-7 dienes. ${ }^{63,64,251,281}$ Two of the products, 21 $(\mathrm{OH}) \mathrm{pD}$ and $3 \beta, 21$-dihydroxy-9 $\beta, 10 \alpha$-pregna-5,7-dien-20one $(21(\mathrm{OH}) \mathrm{pL})$, showed comparable potency to that of $1,25(\mathrm{OH})_{2} \mathrm{D} 3$ for the inhibition of growth of human SKMEL-188 melanoma cells. ${ }^{64}$ In contrast to $1,25(\mathrm{OH})_{2} \mathrm{D} 3$ and $20(\mathrm{OH}) \mathrm{D} 3$, the short side-chain secosteroids $20(\mathrm{OH}) \mathrm{pD}$ and $\mathrm{pD}$ had minimal or no effect on the proliferation of normal primary melanocytes, ${ }^{238}$ with inhibition only seen for the melanotic but not amelanotic immortalized human melanocyte line (PIG1). ${ }^{57}$ Nevertheless, their anti-melanoma efficacy was found to be lower in comparison to hydroxylated analogs of vitamin $\mathrm{D}_{3}$ with a full-length side chain $(25(\mathrm{OH})$ D3, $20(\mathrm{OH}) \mathrm{D} 3, \quad 20,23(\mathrm{OH})_{2} \mathrm{D} 3$ and $\left.1,25(\mathrm{OH})_{2} \mathrm{D} 3\right) .{ }^{238}$ Furthermore, $20(\mathrm{OH}) \mathrm{pD}$ treatment of melanoma cells resulted in inhibition of proliferation but not cell death, while $1,25(\mathrm{OH})_{2} \mathrm{D} 3$ showed antiproliferative and cytotoxic activities. $^{238}$ Overall, short side-chain secosteroids, such as $\mathrm{pD}, 21(\mathrm{OH}) \mathrm{pD}, 17 \alpha, 20 \mathrm{R}(\mathrm{OH})_{2} \mathrm{pD}$ and its lumisterol-like isomer $\left(17 \alpha, 20 \mathrm{~S}(\mathrm{OH})_{2} \mathrm{pL}\right)$ were shown to inhibit colony formation of SKMEL-188 melanoma cells in vitro with at least equal potency to that of $1,25(\mathrm{OH})_{2} \mathrm{D} 3 .^{63,64}$ Also, $20(\mathrm{OH}) \mathrm{pD}$ and its lumisterol-like isomer $20(\mathrm{OH}) \mathrm{pL}$, as well as $21(\mathrm{OH})$ $\mathrm{pD}$, showed anti-melanoma activities against human SKMEL-188, hamster $\mathrm{Ab}$ and $\mathrm{AbC1}$ melanoma lines and the mouse B16-clone F10. ${ }^{63,64,67}$ Similarly, another steroidal derivative with a 5,7-diene moiety, 17-COOH-7DA (3 $\beta$-hydroxyandrosta-5,7-diene-17 $\beta$-carboxylic acid), was found to be more potent than $1,25(\mathrm{OH})_{2} \mathrm{D} 3$ in inhibiting proliferation, colony formation and DNA synthesis by human SKMEL-188, WM35, WM1341 and hamster AbC1 melanoma cell lines. ${ }^{251}$ In addition, anti-melanoma activity of several $\mathrm{pD}$ and $\mathrm{aD}$ secosteroids, including $(5 Z, 7 E)$ - 9,10-secoandrosta$5,7,10(19)$-trien-3 $\beta$-ol were confirmed by examining anchorage-independent growth of SKMEL-188 melanoma cells. ${ }^{280}$

Recently, we speculated that a high concentration of reactive oxygen species (ROS) produced during melanogenesis may have an impact on melanoma biology. ${ }^{211}$ Interestingly, the short side chain secosteroid, $21(\mathrm{OH}) \mathrm{pD}$, similar to $1,25(\mathrm{OH})_{2} \mathrm{D} 3$, was found to aggravate the effect of the model ROS molecule, $\mathrm{H}_{2} \mathrm{O}_{2}$, on human immortalized $\mathrm{HaCaT}$ keratinocytes. ${ }^{276}$ Induction of pigmentation in the SKMEL-188 melanoma line sensitized cells towards treatment with the short side chain lumisterol derivative, $21(\mathrm{OH}) \mathrm{pL}$, while the anti-melanoma potency of the parental compound, $21(\mathrm{OH}) 7 \mathrm{DHP}$, and its vitamin D-like derivative $21(\mathrm{OH}) \mathrm{pD}$, was not affected by pigmentation. ${ }^{64}$ In addition, the antiproliferative activities of $\mathrm{pD}$ and $\mathrm{pL}$ compounds were affected by active melanogenesis in Ab hamster and B16-F10 mouse melanoma cells. ${ }^{67}$

\section{MELANOMA MANAGEMENT: WHAT IS NEW UNDER THE SUN? \\ Targeting Retinoic Acid Orphan Receptors (RORs) in Melanoma Therapy}

Recent studies have demonstrated that certain hydroxylated vitamin $\mathrm{D}$ derivatives can function as inverse agonists for both $\operatorname{ROR} \alpha$ and $\operatorname{ROR} \gamma$ and as a consequence are able to modulate the physiological and molecular processes regulated by these receptors. ${ }^{94}$ This includes regulation of embryonic development, several immune functions and circadian rhythm, as well as lipid and glucose homeostasis. ${ }^{282,283}$ In 
addition, RORs have been implicated in the control of several pathologies, including several (auto)immune diseases, metabolic syndrome, and cancer. The first link between loss of $\mathrm{ROR} \gamma$ function and cancer was observed in ROR $\gamma$-deficient mice, which develop thymic T-cell lymphomas that rapidly metastasize to other tissues. ${ }^{284}$ Subsequent studies showed that ROR $\alpha / \gamma$ expression correlates inversely with tumorigenesis and positively with cancer survival outcomes.

We recently reported that there is an inverse correlation between the level of ROR $\alpha$ and ROR $\gamma$ expression and melanoma progression. ${ }^{285}$ These studies on a series of melanoma biopsy specimens showed that the expression of $\mathrm{ROR} \alpha$ and ROR $\gamma$ decreased with melanoma progression being lowest in most advanced melanomas (Breslow thickness $>2 \mathrm{~mm}$, Clark level $>2$, pT3-4, stages III-IV, cases that developed metastases) and in melanoma metastases. ${ }^{285}$ The presence of markers of poor prognosis (ulceration, absent TILs, nodular type, vertical growth phase) was accompanied by the lowest $\mathrm{ROR} \alpha$ and $\mathrm{ROR} \gamma$ levels. In addition, ROR $\alpha$ and $\mathrm{ROR} \gamma$ expression was inversely correlated with high melanin content, and this result was confirmed in melanoma cells with inducible melanogenesis. Similarly to the VDR, CYP27B1 and CYP24A1, and a lack of or low level of $\operatorname{ROR} \alpha$ or $\operatorname{ROR} \gamma$ correlated to shorter overall and diseases-free survival. ${ }^{285}$

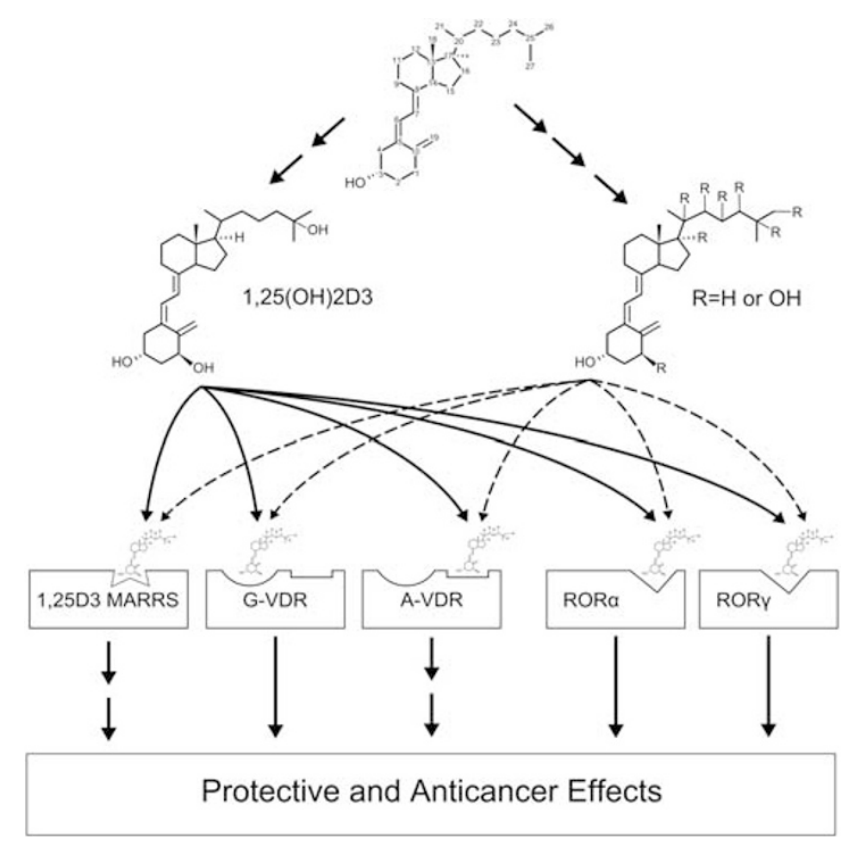

Figure $51,25(\mathrm{OH})_{2} \mathrm{D} 3$ and other active forms of hydroxyvitamin D3 can exert protective and anticancerogeneic effects by interaction with the VDR and/or alternative nuclear or membrane bound receptors. In addition to the classical pathway producing $1,25(\mathrm{OH})_{2} \mathrm{D} 3$, activation of $\mathrm{D} 3$ via combined action of CYP11A1, CYP27A1, CYP27A1 and CYP27B1 produce several hydroxy derivatives that can interact with the VDR, RORa, RORy and 125D3MARRS, depending on the ligand structure. 1,25(OH) 2 D3 can also interact with these receptors in addition to its action on the VDR. $\mathrm{ROR}$, retinoic acid orphan receptor; VDR, vitamin $\mathrm{D}$ receptor.
The above observations are consistent with reports on the level of ROR $\alpha / \gamma$ expression in several other cancers, including breast cancer, non-small cell lung carcinoma, and hepatocellular carcinoma and studies showing a positive association with prognosis. ${ }^{286-290}$ These antitumor effects of RORs have contributed to decreased cell proliferation as well as inhibition of the EMT. ${ }^{286,289,291}$ The inverse correlation between ROR $\alpha / \gamma$ expression and tumorigenesis suggests that agonists might inhibit tumor growth and progression and provide a promising new strategy for anticancer therapy.

A recent study showed that growth of melanoma cells is considerably reduced in $\mathrm{ROR} \gamma$-deficient bone marrow chimeric mice. ${ }^{292}$ Deficiency in ROR $\gamma$ leads to decreased Th17 differentiation and IL-17 levels, but increased IL-9 production. ${ }^{293-295}$ This suppression of tumor growth in this model has been attributed to increased expression of IL-9, which has been reported to promote antitumor immunity. ${ }^{296}$ In this case, inverse agonists/antagonists, such as hydroxylated vitamin $\mathrm{D}$ derivatives, might inhibit tumor growth and progression by promoting antitumor immunity and provide an alternative therapeutic strategy. However, ROR antagonists, by acting directly on tumor cells, might potentially promote tumor progression by repressing ROR activity. Inversely, ROR agonists might inhibit tumor growth, however, they may reduce antitumor immunity.

\section{Potential use of Novel Nocalcemic Derivatives of Vitamin D}

Despite anti-melanoma activities of $1,25(\mathrm{OH})_{2} \mathrm{D} 3$ described above, a major barrier for its use at pharmacological doses is its toxicity secondary to calcemic activity. $3,9,69,71,127,297$ Although there are more than 3000 chemically synthesized analogs of D3 with low-calcemic effects that target VDR, none of them have entered clinical or preclinical trials in melanoma, and none of them has entered the clinic as a general anticancer drug. A possible limitation on man-made analogs could relate to their relative toxicity $v s$ the optimal antitumor serum concentrations necessary for anticancer activity, their relative resistance to metabolism and high target selectivity. In contrast, D3 of either cutaneous or nutritional source can be metabolized in vivo to a large number of hydroxy derivatives with multiple regulatory targets, potentially resulting in protective and anticancer effects (Figures 1 and 5).

In this context, intermediates and products of an alternative pathway of D3 metabolism initiated by CYP11A1 and producing $20(\mathrm{OH}) \mathrm{D} 3$ as the major product as well as other hydroxy derivatives $(\mathrm{OH})_{\mathrm{n}} \mathrm{D} 3$, represent attractive alternatives for D3-based anti-melanoma therapy. ${ }^{53,175,298}$ It should be noted that these metabolites are detectable in the human body, with $20(\mathrm{OH}) \mathrm{D} 3$ being present in human serum in the $\mathrm{nM}$ range. ${ }^{4,52,54}$ The CYP11A1-derived secosteroids also display biological potency equal to or higher than that of classical $1,25(\mathrm{OH})_{2} \mathrm{D} 3$, with antiproliferative, antitumor, and anti-inflammatory activities on melanoma 
cells. $39,67,94,118,120,272$ The presence of CYP11A1-derived hydroxymetabolites in the human serum suggests that they have hormonal function. Furthermore, $20(\mathrm{OH}) \mathrm{D} 3$ is noncalcemic and nontoxic at pharmacological doses $(30-60 \mu \mathrm{g} / \mathrm{kg})$, which are $>100$ times higher than toxic doses of $1,25(\mathrm{OH})_{2} \mathrm{D} 3$ or its precursor, $25(\mathrm{OH}) \mathrm{D} 3 .^{117,268,272}$ These novel vitamin D hydroxy derivatives could be used as an adjuvant (supplement) to already established melanoma therapies, because of their low toxicity and endogenous origin. Their local metabolism may actually increase their anti-melanoma potency, ${ }^{40}$ with an increased spectrum of regulatory targets (Figure 5). Finally, secosteroids with a short side chain may also serve as excellent candidates for adjuvants in melanoma therapy, because they also lack calcemic activity and some of them are of endogenous origin. ${ }^{63,64,66,67,238,279}$ One caveat on short side chain secosteroids is their immediate target (receptor) for bioregulation is unclear. ${ }^{19,50,238}$

\section{Vitamin D as an Adjuvant in Melanoma Management: An Australian Clinical Trial}

In view of the observed relationship between vitamin $\mathrm{D}$ status and Breslow thickness and outcomes in melanoma patients, ${ }^{104,177,178,299}$ the next question is whether supplementation with vitamin $\mathrm{D}$ at an early stage after diagnosis is safe and improves outcomes in patients with melanoma. Randomized clinical trials to examine these questions are now underway in Belgium, Italy and Australia, though none have reported outcomes as yet. 'Vitamin D supplementation in cutaneous malignant melanoma outcome;' (VIDMe), Clinical Trials.gov Identifier NCT01748448), is a Phase 3 RCT based in Belgium. Melanoma patients, stage Ib to III, will be given oral vitamin D, 100000 IU per month or placebo, for a maximum of 3.5 years or until relapse occurs. The primary outcome is relapse-free survival. The MelaViD trial in Italy $^{300}$ is an RCT, with resected stage II melanoma patients randomized to 100000 IU every 50 days or so (approx. $2000 \mathrm{IU} /$ day). The primary outcome is disease-free survival. The Mel-D trial, a phase II RCT conducted by the Australia and New Zealand Melanoma Trials Group, ${ }^{301}$ involves randomization of 75 patients with stage IIb, c or stage IIIa, b melanoma within 9 weeks of wide excision of the primary, in a ratio of 2:1 to active treatment or placebo. These patients are at high risk of recurrence. Active treatment is an oral loading dose of $500000 \mathrm{IU}$ of vitamin D3 followed by an oral dose of $50000 \mathrm{IU}$ monthly for 2 years. The aim of the loading dose is to rapidly increase serum $25(\mathrm{OH}) \mathrm{D}$ concentrations as early as possible in these patients, to mimic, as far as possible, the effect of high vitamin D status at diagnosis. Primary outcomes are dose sufficiency, adherence to medication and safety, with secondary outcome of progression-free survival. To date, there have been few safety concerns, despite the large loading dose.

\section{CONCLUDING REMARKS AND PERSPECTIVE}

In summary, it is becoming unquestionable that defects in vitamin D signaling that include systemic or local defects in vitamin $\mathrm{D}$ activation and inactivation, and in expression and signaling through the corresponding receptors, can affect melanomagenesis, tumor progression, and outcome of the disease (Figure 1). It should also be emphasized that there is more than one form of active vitamin D besides $1,25(\mathrm{OH})_{2} \mathrm{D} 3$ ) and more than one receptor target besides the VDR, which can potentially affect the behavior of melanoma cells and the outcome of the disease or its therapy (Figure 5). From an anatomic pathology point of view, changes in the expression of VDR, CYP27B1, CYP24A1, or RORs could serve as promising markers of melanoma prognosis, or as excellent reference points when considering vitamin $\mathrm{D}$ therapy or pharmacological targeting of the VDR or RORs in melanoma patients. With respect to prevention, testing for SNPs in VDR and perhaps in RORs, CYP27B1 and CYP24A1, may identify subgroups of patients that are at particular risk of developing melanoma. In terms of clinical pathology, measurement of serum 25(OH)D3 and other D3 metabolites including CYP11A1-derived hydroxy derivatives, should represent standard practice since vitamin $\mathrm{D}$ deficiency may affect progression of the disease. While it has to be acknowledged that the use of chemically synthesized vitamin D analogs targeting the VDR has not been successful in cancer therapy to date, nutritional and perhaps parenteral application of vitamin D may represent an excellent adjuvant strategy in cancer management, including melanoma. Furthermore, the discovery of new active hydroxy derivatives of vitamin $\mathrm{D}$ that are noncalcemic and produced in the human body may represent a dawn for their use in cancer management.

In conclusion, while UVB wavelengths of solar radiation can serve as an etiological factor in melanomagenesis, it must be acknowledged that it is also necessary for vitamin D formation that can not only act as a protector against UVR, but also has a role in attenuating carcinogenesis and tumor progression.

\section{ACKNOWLEDGMENTS}

We thank Dr Tae-Kang Kim for the preparation of Figure 1. The work was supported by grants R21AR066505, 1R01AR056666 and 2R01AR052190 from NIH to A.T.S., 1101BX003395-01 from V.A. to C.E., 2014/15/B/NZ4/00751 from National Science Centre, Poland, and CO/ZPNiP/1/2013 from Oncology Centre-Prof. Franciszek Łukaszczyk Memorial Hospital to A.A.B., N405 623238 from the Polish Ministry of Science and Higher Education to M.A.Z., APP1070688 NHMRC, Australia to R.S.M., and the University of Western Australia to R.C.T. Grants R21AR066505, 1R01AR056666 and 2R01AR052190 from NIH, 1101BX003395-01 from V.A., 2014/15/B/NZ4/00751 from National Science Centre, Poland and CO/ZPNiP/1/2013 from Oncology Centre-Prof. Franciszek Łukaszczyk Memorial Hospital, N405 623238 from the Polish Ministry of Science and Higher Education, the University of Western Australia, and APP1070688 NHMRC, Australia.

\section{DISCLOSURE/CONFLICT OF INTEREST}

The authors declare no conflict of interest. 
1. Bikle DD. Vitamin D receptor, UVR, and skin cancer: a potential protective mechanism. J Invest Dermatol 2008;128:2357-2361.

2. Holick MF. Vitamin D: a millenium perspective. J Cell Biochem 2003;88:296-307.

3. Holick MF. Vitamin D deficiency. N Engl J Med 2007;357:266-281.

4. Wacker M, Holick MF. Sunlight and vitamin D: A global perspective for health. Dermatoendocrinol 2013;5:51-108.

5. Holick MF, Frommer JE, McNeill SC, et al. Photometabolism of 7-dehydrocholesterol to previtamin D3 in skin. Biochem Biophys Res Commun 1977;76:107-114.

6. Dixon KM, Norman AW, Sequeira VB, et al. 1alpha,25(OH)(2)-vitamin D and a nongenomic vitamin $\mathrm{D}$ analogue inhibit ultraviolet radiationinduced skin carcinogenesis. Cancer Prev Res (Phila) 2011;4:1485-1494.

7. Kimlin MG, Lucas RM, Harrison SL, et al. The contributions of solar ultraviolet radiation exposure and other determinants to serum 25hydroxyvitamin $D$ concentrations in Australian adults: the AusD Study. Am J Epidemiol 2014;179:864-874.

8. Slominski A, Postlethwaite AE. Skin under the sun: when melanin pigment meets Vitamin D. Endocrinology 2015;156:1-4.

9. Plum LA, DeLuca HF. Vitamin D, disease and therapeutic opportunities. Nat Rev Drug Discov 2010;9:941-955.

10. Miller WL. Genetic disorders of Vitamin D biosynthesis and degradation. J Steroid Biochem Mol Biol 2016;165:101-108.

11. Bikle DD. Vitamin D metabolism and function in the skin. Mol Cell Endocrinol 2011;347:80-89.

12. Bikle DD, Chang S, Crumrine D, et al. 25 Hydroxyvitamin D 1 alphahydroxylase is required for optimal epidermal differentiation and permeability barrier homeostasis. J Invest Dermatol 2004;122:984-992.

13. Bikle DD. Vitamin D and the skin: physiology and pathophysiology. Rev Endocr Metab Disord 2012;13:3-19.

14. Zhu JG, Ochalek JT, Kaufmann M, et al. CYP2R1 is a major, but not exclusive, contributor to 25-hydroxyvitamin D production in vivo. Proc Natl Acad Sci USA 2013;110:15650-15655.

15. Sakaki T, Sawada N, Komai K, et al. Dual metabolic pathway of 25hydroxyvitamin D3 catalyzed by human CYP24. Eur J Biochem 2000;267:6158-6165.

16. Beckman MJ, Tadikonda P, Werner $\mathrm{E}$, et al. Human 25-hydroxyvitamin D3-24-hydroxylase, a multicatalytic enzyme. Biochemistry 1996;35: 8465-8472.

17. Jones G, Prosser DE, Kaufmann M. Cytochrome P450-mediated metabolism of vitamin D. J Lipid Res 2014;55:13-31.

18. Tieu EW, Tang EK, Tuckey RC. Kinetic analysis of human CYP24A1 metabolism of vitamin D via the C24-oxidation pathway. FEBS J 2014;281:3280-3296.

19. Slominski AT, Li W, Kim TK, et al. Novel activities of CYP11A1 and their potential physiological significance. J Steroid Biochem Mol Biol 2015; 151:25-37.

20. Downs JR, Clearfield M, Weis $S$, et al. Primary prevention of acute coronary events with lovastatin in men and women with average cholesterol levels: results of AFCAPS/TexCAPS. Air Force/Texas Coronary Atherosclerosis Prevention Study. JAMA 1998;279: 1615-1622.

21. Linden KG, Leachman SA, Zager JS, et al. A randomized, double-blind, placebo-controlled phase II clinical trial of lovastatin for various endpoints of melanoma pathobiology. Cancer Prev Res (Phila) 2014;7: 496-504.

22. Freeman SR, Drake AL, Heilig LF, et al. Statins, fibrates, and melanoma risk: a systematic review and meta-analysis. J Natl Cancer Inst 2006;98: 1538-1546.

23. Jakobisiak M, Golab J. Potential antitumor effects of statins (review). Int J Oncol 2003;23:1055-1069.

24. Glynn SA, O'Sullivan D, Eustace AJ, et al. The 3-hydroxy-3methylglutaryl-coenzyme A reductase inhibitors, simvastatin, lovastatin and mevastatin inhibit proliferation and invasion of melanoma cells. BMC Cancer 2008;8:9.

25. Yavuz B, Ertugrul DT, Cil H, et al. Increased levels of 25 hydroxyvitamin $D$ and 1,25-dihydroxyvitamin D after rosuvastatin treatment: a novel pleiotropic effect of statins? Cardiovasc Drugs Ther 2009;23:295-299.

26. Ott C, Raff U, Schneider MP, et al. 25-hydroxyvitamin D insufficiency is associated with impaired renal endothelial function and both are improved with rosuvastatin treatment. Clin Res Cardiol 2013;102: 299-304.
27. Lips $P$, Bouillon $R$, van Schoor NM, et al. Reducing fracture risk with calcium and vitamin D. Clin Endocrinol (Oxf) 2010;73:277-285.

28. Bischoff-Ferrari HA, Dietrich T, Orav EJ, et al. Higher 25-hydroxyvitamin $\mathrm{D}$ concentrations are associated with better lower-extremity function in both active and inactive persons aged $>$ or $=60 \mathrm{y}$. Am J Clin Nutr 2004:80:752-758.

29. Bischoff-Ferrari HA, Dawson-Hughes B, Staehelin HB, et al. Fall prevention with supplemental and active forms of vitamin D: a metaanalysis of randomised controlled trials. BMJ 2009;339:b3692.

30. Tang BM, Eslick GD, Nowson C, et al. Use of calcium or calcium in combination with vitamin $\mathrm{D}$ supplementation to prevent fractures and bone loss in people aged 50 years and older: a meta-analysis. Lancet 2007;370:657-666.

31. Boonen $\mathrm{S}$, Lips $\mathrm{P}$, Bouillon $\mathrm{R}$, et al. Need for additional calcium to reduce the risk of hip fracture with vitamin $d$ supplementation: evidence from a comparative metaanalysis of randomized controlled trials. J Clin Endocrinol Metab 2007;92:1415-1423.

32. Group D. Patient level pooled analysis of 68500 patients from seven major vitamin D fracture trials in US and Europe. BMJ 2010:340:b5463.

33. Rejnmark L, Avenell A, Masud T, et al. Vitamin D with calcium reduces mortality: patient level pooled analysis of 70,528 patients from eight major vitamin D trials. J Clin Endocrinol Metab 2012;97:2670-2681.

34. Grant WB. An estimate of premature cancer mortality in the U.S. due to inadequate doses of solar ultraviolet-B radiation. Cancer 2002;94: 1867-1875.

35. Slominski A, Semak I, Zjawiony J, et al. The cytochrome P450scc system opens an alternate pathway of vitamin D3 metabolism. FEBS J 2005;272:4080-4090.

36. Slominski A, Semak I, Wortsman J, et al. An alternative pathway of vitamin D metabolism. Cytochrome P450scc (CYP11A1)-mediated conversion to 20-hydroxyvitamin D2 and 17,20-dihydroxyvitamin D2. FEBS J 2006;273:2891-2901.

37. Tuckey RC, Li W, Zjawiony JK, et al. Pathways and products for the metabolism of vitamin D3 by cytochrome P450scc. FEBS J 2008;275: 2585-2596.

38. Nguyen MN, Slominski A, Li W, et al. Metabolism of vitamin D2 to 17,20,24-trihydroxyvitamin D2 by cytochrome p450scc (CYP11A1). Drug Metab Dispos 2009;37:761-767.

39. Slominski AT, Kim TK, Janjetovic Z, et al. 20-Hydroxyvitamin D2 is a noncalcemic analog of vitamin $D$ with potent antiproliferative and prodifferentiation activities in normal and malignant cells. Am J Physiol Cell Physiol 2011;300:C526-C541.

40. Tang EK, Chen J, Janjetovic Z, et al. Hydroxylation of CYP11A1-derived products of vitamin D3 metabolism by human and mouse CYP27B1. Drug Metab Dispos 2013;41:1112-1124.

41. Tieu EW, Li W, Chen J, et al. Metabolism of 20-hydroxyvitamin D3 and 20,23-dihydroxyvitamin D3 by rat and human CYP24A1. J Steroid Biochem Mol Biol 2015;149:153-165.

42. Tang EK, Li W, Janjetovic Z, et al. Purified mouse CYP27B1 can

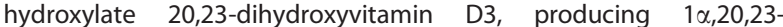
trihydroxyvitamin D3, which has altered biological activity. Drug Metab Dispos 2010;38:1553-1559.

43. Tieu EW, Li W, Chen J, et al. Metabolism of cholesterol, vitamin D3 and 20-hydroxyvitamin D3 incorporated into phospholipid vesicles by human CYP27A1. J Steroid Biochem Mol Biol 2012;129:163-171.

44. Slominski AT, Kim TK, Shehabi HZ, et al. In vivo evidence for a novel pathway of vitamin $\mathrm{D}(3)$ metabolism initiated by P450scc and modified by CYP27B1. FASEB J 2012;26:3901-3915.

45. Slominski AT, Kim TK, Shehabi HZ, et al. In vivo production of novel vitamin D2 hydroxy-derivatives by human placentas, epidermal keratinocytes, Caco-2 colon cells and the adrenal gland. Mol Cell Endocrinol 2014;383:181-192.

46. Tuckey RC, Nguyen MN, Slominski A. Kinetics of vitamin D3 metabolism by cytochrome P450scc (CYP11A1) in phospholipid vesicles and cyclodextrin. Int J Biochem Cell Biol 2008;40: 2619-2626.

47. Tuckey RC, Li W, Shehabi HZ, et al. Production of 22-hydroxy metabolites of vitamin D3 by cytochrome P450scc (CYP11A1) and analysis of their biological activities on skin cells. Drug Metab Dispos 2011:39:1577-1588.

48. Tuckey RC. Progesterone synthesis by the human placenta. Placenta 2005;26:273-281. 
49. Miller WL, Auchus RJ. The molecular biology, biochemistry, and physiology of human steroidogenesis and its disorders. Endocrine Reviews 2011;32:81-151.

50. Slominski AT, Manna PR, Tuckey RC. On the role of skin in the regulation of local and systemic steroidogenic activities. Steroids 2015;103:72-88.

51. Slominski AT, Kim TK, Li W, et al. Classical and non-classical metabolic transformation of vitamin $D$ in dermal fibroblasts. Exp Dermatol 2016;25:231-232.

52. Slominski AT, Kim TK, Li W, et al. Detection of novel CYP11A1-derived secosteroids in the human epidermis and serum and pig adrenal gland. Sci Rep 2015;5:14875.

53. Slominski AT, Kim TK, Li W, et al. The role of CYP11A1 in the production of vitamin $D$ metabolites and their role in the regulation of epidermal functions. J Steroid Biochem Mol Biol 2014;144PA:28-39.

54. Slominski AT, Janjetovic Z, Kim TK, et al. Novel non-calcemic secosteroids that are produced by human epidermal keratinocytes protect against solar radiation. J Steroid Biochem Mol Biol 2015;148: 52-63.

55. Guryev O, Carvalho RA, Usanov S, et al. A pathway for the metabolism of vitamin D3: unique hydroxylated metabolites formed during catalysis with cytochrome P450scc (CYP11A1). Proc Natl Acad Sci USA 2003;100:14754-14759.

56. Slominski A, Zjawiony J, Wortsman J, et al. A novel pathway for sequential transformation of 7-dehydrocholesterol and expression of the P450scc system in mammalian skin. Eur J Biochem 2004;271: 4178-4188.

57. Slominski AT, Zmijewski MA, Semak I, et al. Sequential metabolism of 7-dehydrocholesterol to steroidal 5,7-dienes in adrenal glands and its biological implication in the skin. PLoS One 2009;4:e4309.

58. Slominski AT, Kim TK, Chen J, et al. Cytochrome P450scc-dependent metabolism of 7-dehydrocholesterol in placenta and epidermal keratinocytes. Int J Biochem Cell Biol 2012;44:2003-2018.

59. Shackleton $\mathrm{CH}$. Role of a disordered steroid metabolome in the elucidation of sterol and steroid biosynthesis. Lipids 2012;47:1-12.

60. Shackleton C, Roitman E, Guo LW, et al. Identification of 7(8) and 8(9) unsaturated adrenal steroid metabolites produced by patients with 7-dehydrosterol-delta7-reductase deficiency (Smith-Lemli-Opitz syndrome). J Steroid Biochem Mol Biol 2002;82:225-232.

61. Schuster I. Cytochromes P450 are essential players in the vitamin D signaling system. Biochim Biophys Acta 2011;1814:186-199.

62. Zmijewski MA, Li W, Zjawiony JK, et al. Synthesis and photoconversion of androsta- and pregna-5,7-dienes to vitamin D3-like derivatives. Photochem Photobiol Sci 2008;7:1570-1576.

63. Zmijewski MA, Li W, Zjawiony JK, et al. Photo-conversion of two epimers (20R and 20S) of pregna-5,7-diene-3beta, 17alpha, 20-triol and their bioactivity in melanoma cells. Steroids 2009;74:218-228.

64. Zmijewski MA, Li W, Chen J, et al. Synthesis and photochemical transformation of 3beta,21-dihydroxypregna-5,7-dien-20-one to novel secosteroids that show anti-melanoma activity. Steroids 2011;76:193-203.

65. Slominski A, Kim TK, Zmijewski MA, et al. Novel vitamin D photoproducts and their precursors in the skin. Dermato-Endocrinol 2013:5:1-13.

66. Slominski AT, Li W, Bhattacharya SK, et al. Vitamin D analogs 17,20S $(\mathrm{OH}) 2 \mathrm{pD}$ and $17,20 \mathrm{R}(\mathrm{OH}) 2 \mathrm{pD}$ are noncalcemic and exhibit antifibrotic activity. J Invest Dermatol 2011;131:1167-1169.

67. Wasiewicz T, Szyszka P, Cichorek M, et al. Antitumor effects of vitamin $D$ analogs on hamster and mouse melanoma cell lines in relation to melanin pigmentation. Int J Mol Sci 2015;16:6645-6667.

68. Tuckey RC, Slominski AT, Cheng CY, et al. Lumisterol is metabolized by CYP11A1: discovery of a new pathway. Int J Biochem Cell Biol 2014;55:24-34

69. Fleet JC, DeSmet $M$, Johnson $R$, et al. Vitamin $D$ and cancer: a review of molecular mechanisms. Biochem J 2012;441:61-76.

70. Carlberg C. What do we learn from the genome-wide perspective on vitamin D3? Anticancer Res 2015;35:1143-1151.

71. Christakos S, Dhawan P, Verstuyf A, et al. Vitamin D: metabolism, molecular mechanism of action, and pleiotropic effects. Physiol Rev 2016:96:365-408.

72. Bikle DD, Oda Y, Tu CL, et al. Novel mechanisms for the vitamin D receptor (VDR) in the skin and in skin cancer. J Steroid Biochem Mol Biol 2015;148:47-51.
73. Bouillon $\mathrm{R}$, Carmeliet $\mathrm{G}$, Verlinden $\mathrm{L}$, et al. Vitamin $\mathrm{D}$ and human health: lessons from vitamin $D$ receptor null mice. Endocr Rev 2008;29:726-776.

74. Singarapu KK, Zhu J, Tonelli $\mathrm{M}$, et al. Ligand-specific structural changes in the vitamin D receptor in solution. Biochemistry 2011;50: 11025-11033.

75. Norman AW. Minireview: vitamin D receptor: new assignments for an already busy receptor. Endocrinology 2006;147:5542-5548.

76. Mizwicki MT, Norman AW. The vitamin D sterol-vitamin D receptor ensemble model offers unique insights into both genomic and rapidresponse signaling. Sci Signal 2009;2:re4.

77. Moore DD, Kato S, Xie W, et al. International Union of Pharmacology. LXII. The NR1H and NR1I receptors: constitutive androstane receptor, pregnene $X$ receptor, farnesoid $X$ receptor alpha, farnesoid $X$ receptor beta, liver $X$ receptor alpha, liver $X$ receptor beta, and vitamin $D$ receptor. Pharmacol Rev 2006;58:742-759.

78. Carlberg C, Molnar F. Vitamin D receptor signaling and its therapeutic implications: Genome-wide and structural view. Can J Physiol Pharmacol 2015:93:311-318.

79. Reichrath J, Collins ED, Epple S, et al. Immunohistochemical detection of 1,25-dihydroxyvitamin D3 receptors (VDR) in human skin. A comparison of five antibodies. Pathol Res Pract 1996;192:281-289.

80. Bikle DD. Vitamin D receptor, a tumor suppressor in skin. Can J Physiol Pharmacol 2015;93:349-354.

81. Bikle DD, Elalieh $\mathrm{H}$, Welsh $\mathrm{J}$, et al. Protective role of vitamin D signaling in skin cancer formation. J Steroid Biochem Mol Biol 2013;136:271-279.

82. Dixon KM, Tongkao-On $\mathrm{W}$, Sequeira VB, et al. Vitamin $\mathrm{d}$ and death by sunshine. Int J Mol Sci 2013;14:1964-1977.

83. Song EJ, Gordon-Thomson C, Cole L, et al. 1alpha,25-Dihydroxyvitamin D3 reduces several types of UV-induced DNA damage and contributes to photoprotection. J Steroid Biochem Mol Biol 2013;136: 131-138.

84. Xie Z, Komuves $\mathrm{L}, \mathrm{Yu} \mathrm{QC}$, et al. Lack of the vitamin D receptor is associated with reduced epidermal differentiation and hair follicle growth. J Invest Dermatol 2002;118:11-16.

85. Teichert A, Elalieh $\mathrm{H}$, Bikle D. Disruption of the hedgehog signaling pathway contributes to the hair follicle cycling deficiency in Vdr knockout mice. J Cell Physiol 2010;225:482-489.

86. Mady LJ, Ajibade DV, Hsaio C, et al. The transient role for calcium and vitamin D during the developmental hair follicle cycle. J Invest Dermatol 2016;136:1337-1345.

87. Cannell JJ, Grant WB, Holick MF. Vitamin D and inflammation. Dermatoendocrinol 2014;6:e983401.

88. Holick MF. Biological effects of sunlight, ultraviolet radiation, visible light, infrared radiation and vitamin D for health. Anticancer Res 2016;36:1345-1356.

89. Mizwicki MT, Keidel D, Bula CM, et al. Identification of an alternative ligand-binding pocket in the nuclear vitamin $\mathrm{D}$ receptor and its functional importance in 1alpha,25(OH)2-vitamin D3 signaling. Proc Natl Acad Sci USA 2004;101:12876-12881.

90. Boland RL. VDR activation of intracellular signaling pathways in skeletal muscle. Mol Cell Endocrinol 2011;347:11-16.

91. Haussler MR, Jurutka PW, Mizwicki M, et al. Vitamin D receptor (VDR)mediated actions of 1alpha, $25(\mathrm{OH})(2)$ vitamin $\mathrm{D}(3)$ : genomic and nongenomic mechanisms. Best Pract Res Clin Endocrinol Metab 2011;25: 543-559.

92. Khanal R, Nemere I. Membrane receptors for vitamin D metabolites. Crit Rev Eukaryot Gene Expr 2007:17:31-47.

93. Sequeira VB, Rybchyn MS, Tongkao-On W, et al. The role of the vitamin $D$ receptor and ERp57 in photoprotection by 1alpha, 25-dihydroxyvitamin D3. Mol Endocrinol 2012;26:574-582.

94. Slominski AT, Kim TK, Takeda Y, et al. ROR $\alpha$ and ROR $\gamma$ are expressed in human skin and serve as receptors for endogenously produced noncalcemic 20-hydroxy- and 20,23-dihydroxyvitamin D. FASEB J 2014;28:2775-2789.

95. Slominski AT, Kim TK, Hobrath JV, et al. Endogenously produced nonclassical vitamin D hydroxy-metabolites act as 'biased' agonists on VDR and inverse agonists on ROR $\alpha$ and ROR $\gamma$. J Steroid Biochem Mol Biol 2016; doi: 10.1016/j.jsbmb.2016.09.024 [e-pub ahead of print].

96. Slominski AT, Zmijewski MA, Jetten AM. RORa is not a receptor for melatonin (response to DOI 10.1002/bies.201600018). BioEssays 2016:38:1193-1194. 
97. Garland CF, Garland FC. Do sunlight and vitamin D reduce the likelihood of colon cancer? Int J Epidemiol 1980;9:227-231.

98. Engel P, Fagherazzi G, Mesrine $S$, et al. Joint effects of dietary vitamin $\mathrm{D}$ and sun exposure on breast cancer risk: results from the French E3N cohort. Cancer Epidemiol Biomarkers Prev 2011;20:187-198.

99. Garland CF, Comstock GW, Garland FC, et al. Serum 25-hydroxyvitamin $D$ and colon cancer: eight-year prospective study. Lancet 1989;2:1176-1178.

100. Ahonen $\mathrm{MH}$, Tenkanen $\mathrm{L}$, Teppo $\mathrm{L}$, et al. Prostate cancer risk and prediagnostic serum 25-hydroxyvitamin D levels (Finland). Cancer Causes Control 2000;11:847-852.

101. Giovannucci E, Liu Y, Willett WC. Cancer incidence and mortality and vitamin $D$ in black and white male health professionals. Cancer Epidemiol Biomarkers Prev 2006;15:2467-2472.

102. Tretli S, Hernes E, Berg JP, et al. Association between serum 25(OH)D and death from prostate cancer. Br J Cancer 2009;100:450-454.

103. Idorn LW, Philipsen PA, Wulf HC. Sun exposure before and after a diagnosis of cutaneous malignant melanoma: estimated by developments in serum vitamin D, skin pigmentation and interviews. Br J Dermatol 2011;165:164-170.

104. Newton-Bishop JA, Beswick S, Randerson-Moor J, et al. Serum 25hydroxyvitamin D3 levels are associated with breslow thickness at presentation and survival from melanoma. J Clin Oncol 2009;27: 5439-5444.

105. Grant WB. Roles of solar UVB and vitamin D in reducing cancer risk and increasing survival. Anticancer Res 2016;36:1357-1370.

106. Moukayed M, Grant WB. Molecular link between vitamin D and cancer prevention. Nutrients 2013;5:3993-4021.

107. Zinser GM, Sundberg JP, Welsh J. Vitamin $\mathrm{D}(3)$ receptor ablation sensitizes skin to chemically induced tumorigenesis. Carcinogenesis 2002;23:2103-2109.

108. Eisman JA, Martin TJ, Maclntyre I, et al. 1,25-dihydroxyvitamin-Dreceptor in breast cancer cells. Lancet 1979;2:1335-1336.

109. Huerta S, Irwin RW, Heber D, et al. 1alpha,25-(OH)(2)-D(3) and its synthetic analogue decrease tumor load in the $\mathrm{Apc}(\mathrm{min})$ Mouse. Cancer Res 2002;62:741-746.

110. Seubwai W, Wongkham C, Puapairoj A, et al. 22-oxa-1, 25-dihydroxyvitamin D3 efficiently inhibits tumor growth in inoculated mice and primary histoculture of cholangiocarcinoma. Cancer 2010;116:5535-5543.

111. Colston K, Colston MJ, Feldman D. 1,25-dihydroxyvitamin D3 and malignant melanoma: the presence of receptors and inhibition of cell growth in culture. Endocrinology 1981;108:1083-1086.

112. Gonzalez-Pardo V, Martin D, Gutkind JS, et al. 1 Alpha,25-dihydroxyvitamin D3 and its TX527 analog inhibit the growth of endothelial cells transformed by Kaposi sarcoma-associated herpes virus $\mathrm{G}$ proteincoupled receptor in vitro and in vivo. Endocrinology 2010;151:23-31.

113. Wu W, Zhang $X$, Zanello LP. 1alpha,25-Dihydroxyvitamin D(3) antiproliferative actions involve vitamin $D$ receptor-mediated activation of MAPK pathways and AP-1/p21(waf1) upregulation in human osteosarcoma. Cancer Lett 2007;254:75-86.

114. Hager G, Formanek M, Gedlicka C, et al. 1,25(OH)2 vitamin D3 induces elevated expression of the cell cycle-regulating genes P21 and P27 in squamous carcinoma cell lines of the head and neck. Acta Otolaryngol 2001;121:103-109.

115. Chen TC, Holick MF. Hexafluoro-1,25-dihydroxyvitamin D3 has markedly increased potency in inhibiting proliferation of cultured human keratinocytes compared with 1,25-dihydroxyvitamin D3. Br J Dermatol 2000;143:72-78.

116. Janjetovic Z, Tuckey RC, Nguyen MN, et al. 20,23-dihydroxyvitamin D3, novel P450scc product, stimulates differentiation and inhibits proliferation and NF-kappaB activity in human keratinocytes. J Cell Physiol 2010;223:36-48.

117. Slominski AT, Janjetovic Z, Fuller BE, et al. Products of vitamin D3 or 7-dehydrocholesterol metabolism by cytochrome P450scc show anti-leukemia effects, having low or absent calcemic activity. PLoS One 2010;5:e9907.

118. Slominski AT, Janjetovic Z, Kim TK, et al. Novel vitamin D hydroxyderivatives inhibit melanoma growth and show differential effects on normal melanocytes. Anticancer Res 2012;32:3733-3742.

119. Tieu EW, Tang EK, Chen J, et al. Rat CYP24A1 acts on 20-hydroxyvitamin $\mathrm{D}(3)$ producing hydroxylated products with increased biological activity. Biochem Pharmacol 2012;84:1696-1704.
120. Janjetovic Z, Brozyna AA, Tuckey RC, et al. High basal NF-kappaB activity in nonpigmented melanoma cells is associated with an enhanced sensitivity to vitamin D3 derivatives. Br J Cancer 2011;105: 1874-1884.

121. Kanemaru M, Maehara N, Chijiiwa K. Antiproliferative effect of 1alpha,25-dihydroxyvitamin D3 involves upregulation of cyclindependent kinase inhibitor p21 in human pancreatic cancer cells. Hepatogastroenterology 2013;60:1199-1205.

122. Blutt SE, Allegretto EA, Pike JW, et al. 1,25-dihydroxyvitamin D3 and 9-cis-retinoic acid act synergistically to inhibit the growth of LNCaP prostate cells and cause accumulation of cells in G1. Endocrinology 1997;138:1491-1497.

123. Flores $\mathrm{O}$, Wang $\mathrm{Z}$, Knudsen $\mathrm{KE}$, et al. Nuclear targeting of cyclindependent kinase 2 reveals essential roles of cyclin-dependent kinase 2 localization and cyclin $\mathrm{E}$ in vitamin D-mediated growth inhibition. Endocrinology 2010;151:896-908.

124. Colston KW, Perks CM, Xie SP, et al. Growth inhibition of both MCF-7 and Hs578T human breast cancer cell lines by vitamin D analogues is associated with increased expression of insulin-like growth factor binding protein-3. J Mol Endocrinol 1998;20:157-162.

125. Huynh H, Pollak M, Zhang JC. Regulation of insulin-like growth factor (IGF) II and IGF binding protein 3 autocrine loop in human PC-3 prostate cancer cells by vitamin D metabolite $1,25(\mathrm{OH}) 2 \mathrm{D} 3$ and its analog EB1089. Int J Oncol 1998;13:137-143.

126. Sprenger CC, Peterson A, Lance R, et al. Regulation of proliferation of prostate epithelial cells by 1,25-dihydroxyvitamin D3 is accompanied by an increase in insulin-like growth factor binding protein-3. J Endocrinol 2001;170:609-618.

127. Feldman D, Krishnan AV, Swami $S$, et al. The role of vitamin $D$ in reducing cancer risk and progression. Nat Rev Cancer 2014;14:342-357.

128. Murthy S, Weigel NL. 1alpha,25-dihydroxyvitamin D3 induced growth inhibition of $\mathrm{PC}-3$ prostate cancer cells requires an active transforming growth factor beta signaling pathway. Prostate 2004;59: 282-291.

129. Proietti S, Cucina A, D'Anselmi F, et al. Melatonin and vitamin D3 synergistically down-regulate Akt and MDM2 leading to TGFbeta-1dependent growth inhibition of breast cancer cells. J Pineal Res 2011;50:150-158.

130. Park WH, Seol JG, Kim ES, et al. The induction of apoptosis by a combined 1,25(OH)2D3 analog, EB1089 and TGF-beta1 in NCl-H929 multiple myeloma cells. Int J Oncol 2002;20:533-542.

131. Chen S, Zhu J, Zuo S, et al. 1,25(OH)2D3 attenuates TGF-beta1/beta2induced increased migration and invasion via inhibiting epithelialmesenchymal transition in colon cancer cells. Biochem Biophys Res Commun 2015;468:130-135.

132. Campbell MJ, Elstner E, Holden S, et al. Inhibition of proliferation of prostate cancer cells by a 19-nor-hexafluoride vitamin D3 analogue involves the induction of p21waf1, p27kip1 and E-cadherin. J Mol Endocrinol 1997;19:15-27.

133. Lopes N, Carvalho J, Duraes C, et al. 1Alpha,25-dihydroxyvitamin D3 induces de novo E-cadherin expression in triple-negative breast cancer cells by $\mathrm{CDH} 1$-promoter demethylation. Anticancer Res 2012;32:249-257.

134. Uhmann A, Niemann H, Lammering B, et al. Calcitriol inhibits hedgehog signaling and induces vitamin $d$ receptor signaling and differentiation in the patched mouse model of embryonal rhabdomyosarcoma. Sarcoma 2012;2012:357040.

135. Zbytek B, Janjetovic Z, Tuckey RC, et al. 20-Hydroxyvitamin D3, a product of vitamin D3 hydroxylation by cytochrome P450scc, stimulates keratinocyte differentiation. J Invest Dermatol 2008;128: 2271-2280.

136. Axanova LS, Chen YQ, McCoy T, et al. 1,25-dihydroxyvitamin $\mathrm{D}(3)$ and $\mathrm{PI} 3 \mathrm{~K} / \mathrm{AKT}$ inhibitors synergistically inhibit growth and induce senescence in prostate cancer cells. Prostate 2010;70:1658-1671.

137. Uhmann A, Niemann H, Lammering B, et al. Antitumoral effects of calcitriol in basal cell carcinomas involve inhibition of hedgehog signaling and induction of vitamin $\mathrm{D}$ receptor signaling and differentiation. Mol Cancer Ther 2011;10:2179-2188.

138. Deeb KK, Trump DL, Johnson CS. Vitamin D signalling pathways in cancer: potential for anticancer therapeutics. Nat Rev Cancer 2007;7: 684-700.

139. Fleet JC. What have genomic and proteomic approaches told us about vitamin D and cancer? Nutr Rev 2007;65:S127-S130. 
140. Ben-Shoshan M, Amir S, Dang DT, et al. 1alpha,25-dihydroxyvitamin D3 (Calcitriol) inhibits hypoxia-inducible factor-1/vascular endothelial growth factor pathway in human cancer cells. Mol Cancer Ther 2007;6:1433-1439.

141. Mantell DJ, Owens PE, Bundred NJ, et al. 1 alpha,25-dihydroxyvitamin $\mathrm{D}(3)$ inhibits angiogenesis in vitro and in vivo. Circ Res 2000;87: 214-220.

142. Chung I, Han G, Seshadri M, et al. Role of vitamin D receptor in the antiproliferative effects of calcitriol in tumor-derived endothelial cells and tumor angiogenesis in vivo. Cancer Res 2009;69:967-975.

143. Bao BY, Yao J, Lee YF. 1alpha, 25-dihydroxyvitamin D3 suppresses interleukin-8-mediated prostate cancer cell angiogenesis. Carcinogenesis 2006;27:1883-1893.

144. Shintani T, Klionsky DJ. Autophagy in health and disease: a doubleedged sword. Science 2004;306:990-995.

145. Bristol ML, Di X, Beckman MJ, et al. Dual functions of autophagy in the response of breast tumor cells to radiation: cytoprotective autophagy with radiation alone and cytotoxic autophagy in radiosensitization by vitamin D 3. Autophagy 2012;8:739-753.

146. Hoyer-Hansen M, Bastholm L, Mathiasen IS, et al. Vitamin D analog EB1089 triggers dramatic lysosomal changes and Beclin 1-mediated autophagic cell death. Cell Death Differ 2005;12:1297-1309.

147. Sharma K, Goehe R, Beckta JM, et al. Autophagy and radiosensitization in cancer. EXCLI J 2014;13:178-191.

148. Sharma K, Le N, Alotaibi M, et al. Cytotoxic autophagy in cancer therapy. Int J Mol Sci 2014;15:10034-10051.

149. Tavera-Mendoza $L$, Wang $T$, Lallemant B, et al. Convergence of vitamin $\mathrm{D}$ and retinoic acid signalling at a common hormone response element. EMBO Rep 2006;7:180-185.

150. Wilson EN, Bristol ML, Di X, et al. A switch between cytoprotective and cytotoxic autophagy in the radiosensitization of breast tumor cells by chloroquine and vitamin D. Horm Cancer 2011;2:272-285.

151. Lisse TS, Liu T, Irmler $M$, et al. Gene targeting by the vitamin D response element binding protein reveals a role for vitamin $D$ in osteoblast mTOR signaling. FASEB J 2011;25:937-947.

152. Liu H, He Z, Simon HU. Targeting autophagy as a potential therapeutic approach for melanoma therapy. Semin Cancer Biol 2013;23:352-360.

153. Swami S, Krishnan AV, Moreno J, et al. Calcitriol and genistein actions to inhibit the prostaglandin pathway: potential combination therapy to treat prostate cancer. J Nutr 2007;137:205S-210S.

154. Nonn L, Peng L, Feldman D, et al. Inhibition of p38 by vitamin D reduces interleukin- 6 production in normal prostate cells via mitogenactivated protein kinase phosphatase 5: implications for prostate cancer prevention by vitamin D. Cancer Res 2006;66:4516-4524.

155. Tse AK, Wan CK, Shen $\mathrm{XL}$, et al. 1,25-dihydroxyvitamin D3 induces biphasic NF-kappaB responses during HL-60 leukemia cells differentiation through protein induction and PI3K/Akt-dependent phosphorylation/degradation of IkappaB. Exp Cell Res 2007;313: 1722-1734.

156. Hewison M. An update on vitamin D and human immunity. Clin Endocrinol (Oxf) 2012;76:315-325.

157. English DR, Armstrong BK, Kricker A, et al. Demographic characteristics, pigmentary and cutaneous risk factors for squamous cell carcinoma of the skin: a case-control study. Int J Cancer 1998;76: 628-634

158. Mason RS, Reichrath J. Sunlight vitamin D and skin cancer. Anticancer Agents Med Chem 2013;13:83-97.

159. Slominski AT, Zmijewski MA, Semak I, et al. Cytochromes P450 and skin cancer: role of local endocrine pathways. Anticancer Agents Med Chem 2014;14:77-96.

160. Gilchrest BA, Eller MS, Geller AC, et al. The pathogenesis of melanoma induced by ultraviolet radiation. N Engl J Med 1999;340:1341-1348.

161. Dillon $\mathrm{P}$, Thomas N, Sharpless N, et al. Regression of advanced melanoma upon withdrawal of immunosuppression: case series and literature review. Med Oncol 2010;27:1127-1132.

162. Kong Y, Kumar SM, Xu X. Molecular pathogenesis of sporadic melanoma and melanoma-initiating cells. Arch Pathol Lab Med 2010;134:1740-1749.

163. Wang HT, Choi B, Tang MS. Melanocytes are deficient in repair of oxidative DNA damage and UV-induced photoproducts. Proc Nat Acad Sci USA 2010;107:12180-12185.

164. Miller KD, Siegel RL, Lin CC, et al. Cancer treatment and survivorship statistics. 2016CA Cancer J Clin 2016;66:271-289.
165. Siegel RL, Miller KD, Jemal A. Cancer statistics. Cancer J Clin 2016;66: 7-30.

166. Miller AJ, Mihm Jr MCJr. Melanoma. N Engl J Med 2006;355:51-65.

167. Carlson JA, Ross JS, Slominski A, et al. Molecular diagnostics in melanoma. J Am Acad Dermatol 2005;52:743-775, quiz 775-748.

168. Schadendorf D, Fisher DE, Garbe C, et al. Melanoma. Nat Rev Dis Primers 2015;1:15003.

169. Lo JA, Fisher DE. The melanoma revolution: from UV carcinogenesis to a new era in therapeutics. Science 2014;346:945-949.

170. Schadendorf D, Hauschild A. Melanoma in 2013: Melanoma-the run of success continues. Nat Rev Clin Oncol 2014;11:75-76.

171. Shah DJ, Dronca RS. Latest advances in chemotherapeutic, targeted, and immune approaches in the treatment of metastatic melanoma. Mayo Clin Proc 2014;89:504-519.

172. Kwong LN, Davies MA. Targeted therapy for melanoma: rational combinatorial approaches. Oncogene 2014;33:1-9.

173. Rajkumar S, Watson IR. Molecular characterisation of cutaneous melanoma: creating a framework for targeted and immune therapies. Br J Cancer 2016:115:145-155.

174. Nikolaou V, Stratigos AJ. Emerging trends in the epidemiology of melanoma. Br J Dermatol 2014;170:11-19.

175. Slominski AT, Carlson JA. Melanoma resistance: a bright future for academicians and a challenge for patient advocates. Mayo Clin Proc 2014;89:429-433.

176. Newton-Bishop JA, Davies JR, Latheef F, et al. 25-Hydroxyvitamin D2 /D3 levels and factors associated with systemic inflammation and melanoma survival in the Leeds Melanoma Cohort. Int J Cancer 2015;136:2890-2899.

177. Wyatt C, Lucas RM, Hurst C, et al. Vitamin D deficiency at melanoma diagnosis is associated with higher Breslow thickness. PLoS One 2015;10:e0126394.

178. Randerson-Moor JA, Taylor JC, Elliott F, et al. Vitamin D receptor gene polymorphisms, serum 25-hydroxyvitamin D levels, and melanoma: UK case-control comparisons and a meta-analysis of published VDR data. Eur J Cancer 2009:45:3271-3281.

179. Caini S, Boniol M, Tosti G, et al. Vitamin D and melanoma and nonmelanoma skin cancer risk and prognosis: a comprehensive review and meta-analysis. Eur J Cancer 2014;50:2649-2658.

180. Field S, Davies J, Bishop DT, et al. Vitamin D and melanoma. Dermatoendocrinol 2013;5:121-129.

181. Berwick M, Erdei EO. Vitamin D and melanoma incidence and mortality. Pigment Cell Melanoma Res 2013;26:9-15.

182. Ogbah Z, Visa L, Badenas C, et al. Serum 25-hydroxyvitamin D3 levels and vitamin $D$ receptor variants in melanoma patients from the Mediterranean area of Barcelona. BMC Med Genet 2013;14:26.

183. Davies JR, Field S, Randerson-Moor J, et al. An inherited variant in the gene coding for vitamin D-binding protein and survival from cutaneous melanoma: a BioGenoMEL study. Pigment Cell Melanoma Res 2014;27:234-243.

184. Pena-Chilet M, Ibarrola-Villava M, Martin-Gonzalez M, et al. rs12512631 on the group specific complement (vitamin D-binding protein GC) implicated in melanoma susceptibility. PLoS One 2013;8:e59607.

185. Orlow I, Reiner AS, Thomas NE, et al. Vitamin D receptor polymorphisms and survival in patients with cutaneous melanoma: a population-based study. Carcinogenesis 2016;37:30-38.

186. Orlow I, Roy $P$, Reiner AS, et al. Vitamin D receptor polymorphisms in patients with cutaneous melanoma. Int J Cancer 2012;130:405-418.

187. Mandelcorn-Monson R, Marrett L, Kricker A, et al. Sun exposure, vitamin D receptor polymorphisms Fokl and Bsml and risk of multiple primary melanoma. Cancer Epidemiol 2011;35:e105-e110.

188. Mocellin S, Nitti D. Vitamin D receptor polymorphisms and the risk of cutaneous melanoma: a systematic review and meta-analysis. Cancer 2008;113:2398-2407.

189. Gapska P, Scott RJ, Serrano-Fernandez $P$, et al. Vitamin D receptor variants and the malignant melanoma risk: a population-based study Cancer Epidemiol 2009;33:103-107.

190. Chagani S, Kyryachenko S, Yamamoto Y, et al. In vivo role of vitamin D receptor (VDR) signaling in UVB induced DNA damage and melanocyte homeostasis. J Invest Dermatol 2016;136:2108-2111.

191. Indra AK, Castaneda E, Antal MC et al. Malignant transformation of DMBA/TPA-induced papillomas and nevi in the skin of mice selectively lacking retinoid-X-receptor alpha in epidermal keratinocytes. J Invest Dermatol 2007;127:1250-1260. 
192. Wang Z, Coleman DJ, Bajaj G, et al. RXRalpha ablation in epidermal keratinocytes enhances UVR-induced DNA damage, apoptosis, and proliferation of keratinocytes and melanocytes. J Invest Dermatol 2011;131:177-187.

193. Gordon-Thomson C, Tongkao-on W, Song EJ, et al. Protection from ultraviolet damage and photocarcinogenesis by vitamin D compounds. Adv Exp Med Biol 2014;810:303-328.

194. Reichrath J, Rass K. Ultraviolet damage, DNA repair and vitamin D in nonmelanoma skin cancer and in malignant melanoma: an update. Adv Exp Med Biol 2014;810:208-233.

195. Reichrath J, Reichrath S. Sunlight, vitamin D and malignant melanoma: an update. Adv Exp Med Biol 2014;810:390-405.

196. Reichrath J, Reichrath S, Heyne K, et al. Tumor suppression in skin and other tissues via cross-talk between vitamin D- and p53-signaling Front Physiol 2014;5:166.

197. Szyszka P, Zmijewski MA, Slominski AT. New vitamin D analogs as potential therapeutics in melanoma. Expert Rev Anticancer Ther 2012;12:585-599.

198. Uitterlinden AG, Fang Y, Van Meurs JB, et al. Genetics and biology of vitamin D receptor polymorphisms. Gene 2004;338:143-156.

199. Li C, Liu Z, Wang LE, et al. Haplotype and genotypes of the VDR gene and cutaneous melanoma risk in non-Hispanic whites in Texas: a case-control study. Int J Cancer 2008;122:2077-2084.

200. Li C, Liu Z, Zhang Z, et al. Genetic variants of the vitamin D receptor gene alter risk of cutaneous melanoma. J Invest Dermatol 2007;127: 276-280.

201. Brozyna AA, Jozwicki W, Janjetovic Z, et al. Expression of vitamin D receptor decreases during progression of pigmented skin lesions. Hum Pathol 2011;42:618-631.

202. Brozyna AA, Jozwicki W, Slominski AT. Decreased VDR expression in cutaneous melanomas as marker of tumor progression: new data and analyses. Anticancer Res 2014;34:2735-2743.

203. Van Waes C. NF- $\kappa B$ in development, prevention, and therapy of cancer. Clin Cancer Res 2007;13:1076-1082.

204. Karin M. NF- $\kappa B$ and cancer: mechanisms and targets. Mol Carcinog 2006;45:355-361.

205. Yang J, Zaja-Milatovic S, Thu YM, et al. Molecular determinants of melanoma malignancy: selecting targets for improved efficacy of chemotherapy. Mol Cancer Ther 2009;8:636-647.

206. Yang J, Splittgerber R, Yull FE, et al. Conditional ablation of Ikkb inhibits melanoma tumor development in mice. J Clin Invest 2010;120:2563-2574.

207. Thu YM, Su Y, Yang J, et al. NF-kappaB inducing kinase (NIK) modulates melanoma tumorigenesis by regulating expression of prosurvival factors through the beta-catenin pathway. Oncogene 2012; 31:2580-2592.

208. Slominski A, Kim TK, Brozyna AA, et al. The role of melanogenesis in regulation of melanoma behavior: melanogenesis leads to stimulation of HIF-1 $\alpha$ expression and HIF-dependent attendant pathways. Arch Biochem Biophys 2014;563:79-93.

209. Brozyna AA, Jozwicki W, Carlson JA, et al. Melanogenesis affects overall and disease-free survival in patients with stage III and IV melanoma. Hum Pathol 2013;44:2071-2074.

210. Brozyna AA, Jozwicki W, Roszkowski $\mathrm{K}$, et al. Melanin content in melanoma metastases affects the outcome of radiotherapy. Oncotarget 2016;7:17844-17853.

211. Slominski RM, Zmijewski MA, Slominski AT. The role of melanin pigment in melanoma. Exp Dermatol 2015;24:258-259.

212. Slominski A, Zmijewski MA, Pawelek J. L-tyrosine and L-dihydroxyphenylalanine as hormone-like regulators of melanocyte functions. Pigment Cell Melanoma Res 2012;25:14-27.

213. Slominski A, Tobin DJ, Shibahara S, et al. Melanin pigmentation in mammalian skin and its hormonal regulation. Physiol Rev 2004;84: 1155-1228.

214. Slominski A, Paus R, Mihm MC. Inhibition of melanogenesis as an adjuvant strategy in the treatment of melanotic melanomas: selective review and hypothesis. Anticancer Res 1998;18:3709-3715.

215. Slominski A, Zbytek B, Slominski R. Inhibitors of melanogenesis increase toxicity of cyclophosphamide and lymphocytes against melanoma cells. Int J Cancer 2009:124:1470-1477.

216. Slominski A. Neuroendocrine activity of the melanocyte. Exp Dermatol 2009;18:760-763.
217. Slominski A, Paus R, Schadendorf D. Melanocytes as 'sensory' and regulatory cells in the epidermis. J Theor Biol 1993;164:103-120.

218. Slominski A, Paus R. Are L-tyrosine and L-dopa hormone-like bioregulators? J Theor Biol 1990;143:123-138.

219. Slominski A, Paus R. Bomirski melanomas - a versatile and powerful model for pigment cell and melanoma research (review). Int J Oncol 1993;2:221-228.

220. Slominski A, Moellmann G, Kuklinska E. L-tyrosine, L-dopa, and tyrosinase as positive regulators of the subcellular apparatus of melanogenesis in Bomirski Ab amelanotic melanoma cells. Pigment Cell Res 1989;2:109-116.

221. Flanagan JN, Whitlatch LW, Chen TC, et al. Enhancing 1alpha-hydro xylase activity with the 25-hydroxyvitamin D-1alpha-hydroxylase gene in cultured human keratinocytes and mouse skin. J Invest Dermatol 2001;116:910-914.

222. Radermacher J, Diesel B, Seifert $M$, et al. Expression analysis of CYP27B1 in tumor biopsies and cell cultures. Anticancer Res 2006;26: 2683-2686.

223. Brozyna AA, Jozwicki W, Janjetovic $Z$, et al. Expression of the vitamin D-activating enzyme 1alpha-hydroxylase (CYP27B1) decreases during melanoma progression. Hum Pathol 2013;44:374-387.

224. Jones G, Prosser DE, Kaufmann M. 25-Hydroxyvitamin D-24-hydroxylase (CYP24A1): its important role in the degradation of vitamin D. Arch Biochem Biophys 2012;523:9-18.

225. Anderson MG, Nakane M, Ruan X, et al. Expression of VDR and CYP24A1 mRNA in human tumors. Cancer Chemother Pharmacol 2006;57:234-240.

226. Sakaki T, Yasuda K, Kittaka A, et al. CYP24A1 as a potential target for cancer therapy. Anticancer Agents Med Chem 2014;14:97-108.

227. Brozyna AA, Jochymski C, Janjetovic $Z$, et al. CYP24A1 expression inversely correlates with melanoma progression: clinic-pathological studies. Int J Mol Sci 2014;15:19000-19017.

228. Hibler EA, Klimentidis YC, Jurutka PW, et al. CYP24A1 and CYP27B1 polymorphisms, concentrations of vitamin D metabolites, and odds of colorectal adenoma recurrence. Nutr Cancer 2015;67: 1131-1141.

229. Wang $P$, Zhang $H$, Zhang $Z$, et al. Association of the CYP24A1 rs2296241 polymorphism of the vitamin D catabolism enzyme with hormone-related cancer risk: a meta-analysis. Onco Targets Ther 2015;8:1175-1183.

230. Jacobs ET, Van Pelt C, Forster RE, et al. CYP24A1 and CYP27B1 polymorphisms modulate vitamin D metabolism in colon cancer cells. Cancer Res 2013;73:2563-2573.

231. Slominski A, Zbytek B, Pisarchik A, et al. CRH functions as a growth factor/cytokine in the skin. J Cell Physiol 2006;206:780-791.

232. Carlson KW, Nawy SS, Wei ET, et al. Inhibition of mouse melanoma cell proliferation by corticotropin-releasing hormone and its analogs. Anticancer Res 2001;21:1173-1179.

233. Slominski A, Wortsman J, Pisarchik A, et al. Cutaneous expression of corticotropin-releasing hormone $(\mathrm{CRH})$, urocortin, and $\mathrm{CRH}$ receptors. FASEB J 2001;15:1678-1693.

234. Slominski AT, Zmijewski MA, Zbytek B, et al. Key role of CRF in the skin stress response system. Endocr Rev 2013;34:827-884.

235. Pisarchik A, Slominski AT. Alternative splicing of $\mathrm{CRH}-\mathrm{R} 1$ receptors in human and mouse skin: identification of new variants and their differential expression. FASEB J 2001;15:2754-2756.

236. Zmijewski MA, Slominski AT. Emerging role of alternative splicing of CRF1 receptor in CRF signaling. Acta Biochim Pol 2010;57:1-13.

237. Oikawa A, Nakayasu M. Stimulation of melanogenesis in cultured melanoma cells by calciferols. FEBS Lett 1974;42:32-35.

238. Slominski A, Kim TK, Zmijewski MA, et al. Novel vitamin D photoproducts and their precursors in the skin. Dermatoendocrinol 2013;5:7-19.

239. Frampton RJ, Omond SA, Eisman JA. Inhibition of human cancer cell growth by 1,25-dihydroxyvitamin D3 metabolites. Cancer Res 1983:43:4443-4447.

240. Eisman JA, Sher E, Suva LJ, et al. 1alpha,25-Dihydroxyvitamin D3 specifically induces its own metabolism in a human cancer cell line. Endocrinology 1984;114:1225-1231.

241. Frankel TL, Mason RS, Hersey $P$, et al. The synthesis of vitamin D metabolites by human melanoma cells. J Clin Endocrinol Metab 1983:57:627-631. 
242. Piotrowska A, Wierzbicka J, Nadkarni S, et al. Antiproliferative activity of double point modified analogs of 1,25-dihydroxyvitamin $D_{2}$ against human malignant melanoma cell lines. Int J Mol Sci 2016;17:pii: E76; doi: 10.3390/ijms17010076.

243. Gruber BM, Anuszewska EL. Influence of vitamin D3 metabolites on cell proliferation and cytotoxicity of adriamycin in human normal and neoplastic cells. Toxicol In Vitro 2002;16:663-667.

244. Danielsson C, Fehsel K, Polly P, et al. Differential apoptotic response of human melanoma cells to 1alpha,25-dihydroxyvitamin D3 and its analogues. Cell Death Differ 1998:5:946-952.

245. Danielsson $C$, Törmä $H$, Vahlquist $A$, et al. Positive and negative interaction of 1,25-dihydroxyvitamin D3 and the retinoid CD437 in the induction of human melanoma cell apoptosis. Int J Cancer 1999;81:467-470.

246. Seifert $M$, Rech $M$, Meineke $V$, et al. Differential biological effects of 1,25-dihydroxyVitamin D3 on melanoma cell lines in vitro. J Steroid Biochem Mol Biol 2004;89-90:375-379.

247. Evans SR, Houghton AM, Schumaker L, et al. Vitamin D receptor and growth inhibition by 1,25-dihydroxyvitamin D3 in human malignant melanoma cell lines. J Surg Res 1996;61:127-133.

248. Brenner R, Shabahang M, Houghton $A$, et al. Growth-inhibition of human-melanoma cells by vitamin-d analogs. Oncol Rep 1995;2: 1157-1162.

249. Sertznig $P$, Seifert $M$, Tilgen $W$, et al. Activation of vitamin $D$ receptor (VDR)- and peroxisome proliferator-activated receptor (PPAR)-signaling pathways through $1,25(\mathrm{OH})(2) \mathrm{D}(3)$ in melanoma cell lines and other skin-derived cell lines. Dermatoendocrinol 2009;1:232-238.

250. Reichrath J, Rech $M$, Moeini $M$, et al. In vitro comparison of the vitamin $\mathrm{D}$ endocrine system in 1,25(OH)2D3-responsive and -resistant melanoma cells. Cancer Biol Ther 2007:6:48-55.

251. Kim T-K, Chen J, Li W, et al. A new steroidal 5,7-diene derivative, 3 [beta]-hydroxyandrosta-5, 7-diene-17[ $\beta]$-carboxylic acid, shows potent anti-proliferative activity. Steroids 2010;75:230-239.

252. Pelczynska $M$, Switalska $M$, Maciejewska $M$, et al. Antiproliferative activity of vitamin $\mathrm{D}$ compounds in combination with cytostatics. Anticancer Res 2006;26:2701-2705.

253. Hosoi J, Abe E, Suda T, et al. Regulation of melanin synthesis of B16 mouse melanoma cells by 1alpha,25-dihydroxyvitamin D3 and retinoic acid. Cancer Res 1985:45:1474-1478.

254. Essa S, Denzer N, Mahlknecht U, et al. VDR microRNA expression and epigenetic silencing of vitamin $\mathrm{D}$ signaling in melanoma cells. J Steroid Biochem Mol Biol 2010;121:110-113.

255. Mansur CP, Gordon PR, Ray S, et al. Vitamin D, its precursors, and metabolites do not affect melanization of cultured human melanocytes. J Invest Dermatol 1988;91:16-21.

256. Yudoh K, Matsuno H, Kimura T. 1alpha,25-dihydroxyvitamin D3 inhibits in vitro invasiveness through the extracellular matrix and in vivo pulmonary metastasis of B16 mouse melanoma. J Lab Clin Med 1999;133:120-128.

257. Ishibashi M, Arai M, Tanaka S, et al. Antiproliferative and apoptosisinducing effects of lipophilic vitamins on human melanoma A375 cells in vitro. Biol Pharm Bull 2012;35:10-17.

258. Sauer B, Ruwisch L, Kleuser B. Antiapoptotic action of 1alpha,25dihydroxyvitamin D3 in primary human melanocytes. Melanoma Res 2003:13:339-347.

259. Bogh MK, Schmedes AV, Philipsen PA, et al. Vitamin D production after UVB exposure depends on baseline vitamin $D$ and total cholesterol but not on skin pigmentation. J Invest Dermatol 2010;130: 546-553.

260. Watabe $H$, Soma $Y$, Kawa $Y$, et al. Differentiation of murine melanocyte precursors induced by 1,25-dihydroxyvitamin D3 is associated with the stimulation of endothelin $\mathrm{B}$ receptor expression. J Invest Dermatol 2002;119:583-589.

261. Seifert M, Tilgen W, Reichrath J. Expression of 25-hydroxyvitamin D-1alpha-hydroxylase (1alphaOHase, CYP27B1) splice variants in HaCaT keratinocytes and other skin cells: modulation by culture conditions and UV-B treatment in vitro. Anticancer Res 2009;29:3659-3667.

262. Harant $H$, Spinner $D$, Reddy GS, et al. Natural metabolites of 1alpha,25-dihydroxyvitamin $\mathrm{D}(3)$ retain biologic activity mediated through the vitamin D receptor. J Cell Biochem 2000;78:112-120.

263. Eisman JA, Barkla DH, Tutton PJ. Suppression of in vivo growth of human cancer solid tumor xenografts by 1,25-dihydroxyvitamin D3. Cancer Res 1987:47:21-25.
264. Albert DM, Kumar A, Strugnell SA, et al. Effectiveness of 1alphahydroxyvitamin D2 in inhibiting tumor growth in a murine transgenic pigmented ocular tumor model. Arch Ophthalmol 2004;122: $1365-1369$.

265. Janjetovic Z, Zmijewski MA, Tuckey RC, et al. 20-Hydroxycholecalciferol, product of vitamin D3 hydroxylation by P450scc, decreases NF-kappaB activity by increasing I $\mathrm{KB}$ alpha levels in human keratinocytes. PLoS One 2009;4:e5988.

266. Li W, Chen J, Janjetovic Z, et al. Chemical synthesis of 20S-hydroxyvitamin D3, which shows antiproliferative activity. Steroids 2010;75:926-935.

267. Tuckey RC, Li W, Shehabi HZ, et al. Production of 22-hydroxy-metabolites of vitamin D3 by cytochrome P450scc (CYP11A1) and analysis of their biological activities on skin cells. Drug Metab Dispos 2011;39:1577-1588.

268. Wang J, Slominski A, Tuckey RC, et al. 20-hydroxyvitamin D(3) inhibits proliferation of cancer cells with high efficacy while being non-toxic. Anticancer Res 2012;32:739-746.

269. Slominski A, Janjetovic Z, Kim T-K, et al. Novel vitamin D hydroxyderivatives inhibit melanoma growth and show differential effects on normal melanocytes. Anticancer Res 2012;32:3733-3742.

270. Lu Y, Chen J, Janjetovic Z, et al. Design, synthesis, and biological action of 20R-hydroxyvitamin D3. J Med Chem 2012;55:3573-3577.

271. Kim TK, Wang J, Janjetovic Z, et al. Correlation between secosteroidinduced vitamin $\mathrm{D}$ receptor activity in melanoma cells and computermodeled receptor binding strength. Mol Cell Endocrinol 2012;361: 143-152.

272. Chen J, Wang J, Kim TK, et al. Novel vitamin D analogs as potential therapeutics: metabolism, toxicity profiling, and antiproliferative activity. Anticancer Res 2014:34:2153-2163.

273. Slominski A, Moellmann G, Kuklinska E, et al. Positive regulation of melanin pigmentation by two key substrates of the melanogenic pathway, L-tyrosine and L-dopa. J Cell Sci 1988;89:287-296.

274. Lin Z, Marepally SR, Ma D, et al. Synthesis and biological evaluation of vitamin D3 metabolite 20S,23S-dihydroxyvitamin D3 and Its 23R epimer. J Med Chem 2016;59:5102-5108.

275. Wang Q, Lin Z, Kim TK, et al. Total synthesis of biologically active 20S-hydroxyvitamin D3. Steroids 2015;104:153-162.

276. Piotrowska A, Wierzbicka J, Ślebioda T, et al. Vitamin D derivatives enhance cytotoxic effects of $\mathrm{H} 2 \mathrm{O} 2$ or cisplatin on human keratin ocytes. Steroids 2016:110:49-61.

277. Plum LA, Prahl JM, Ma X, et al. Biologically active noncalcemic analogs of 1alpha,25-dihydroxyvitamin $D$ with an abbreviated side chain containing no hydroxyl. Proc Natl Acad Sci USA 2004;101:6900-6904.

278. Murari MP, Londowski JM, Bollman S, et al. Synthesis and biological activity of 3 beta-hydroxy-9,10-secopregna-5,7,10[19]-triene-20-one: a side chain analogue of vitamin D3. J Steroid Biochem 1982;17:615-619.

279. Holick MF, Garabedian M, Schnoes HK, et al. Relationship of 25-hydro xyvitamin D3 side chain structure to biological activity. J Biol Chem 1975;250:226-230.

280. Slominski A, Tuckey RC, Zmijewski MA, et al. Enzymatic production or chemical synthesis and uses for 5,7-dienes and UVB conversion products thereof. US patent 20140200201 A1. PCT/US2009/001324, Vol. PCT/US2009/001324, PCT/US2009/001324 edn 2009.

281. Zmijewski MA, Li W, Zjawiony JK, et al. Synthesis and photoconversion of androsta- and pregna-5,7-dienes to vitamin D3-like derivatives. Photochem Photobiol Sci 2008:7:1570-1576.

282. Cook DN, Kang HS, Jetten AM. Retinoic acid-related orphan receptors (RORs): regulatory functions in immunity, development, circadian rhythm, and metabolism. Nucl Receptor Res 2015;2:pii: 101185 [e-pub ahead of print 16 Dec 2015].

283. Jetten AM. Retinoid-related orphan receptors (RORs): critical roles in development, immunity, circadian rhythm, and cellular metabolism. Nucl Recept Signal 2009;7:e03.

284. Ueda $E$, Kurebayashi $S$, Sakaue $M$, et al. High incidence of T-cell lymphomas in mice deficient in the retinoid-related orphan receptor ROR $\gamma$. Cancer Res 2002;62:901-909.

285. Brożyna AA, Jóźwicki W, Skobowiat $C$, et al. RORa and RORy expression inversely correlates with human melanoma progression. Oncotarget 2016;7:63261-63282.

286. Fu RD, Qiu CH, Chen HA, et al. Retinoic acid receptor-related receptor alpha $(\mathrm{ROR} \alpha)$ is a prognostic marker for hepatocellular carcinoma. Tumour Biol 2014;35:7603-7610.

287. Lekva T, Berg JP, Heck A, et al. Attenuated RORC expression in the presence of EMT progression in somatotroph adenomas following 
treatment with somatostatin analogs is associated with poor clinical recovery. PLoS One 2013;8:e66927.

288. Oh TG, Bailey P, Dray E, et al. PRMT2 and ROR $\gamma$ expression are associated with breast cancer survival outcomes. Mol Endocrinol 2014;28:1166-1185.

289. Oh TG, Wang SC, Acharya BR, et al. The nuclear receptor, ROR $\gamma$, regulates pathways necessary for breast cancer metastasis. EBioMedicine 2016;6:59-72.

290. Cadenas C, van de Sandt L, Edlund K, et al. Loss of circadian clock gene expression is associated with tumor progression in breast cancer. Cell Cycle 2014;13:3282-3291.

291. Xiong $G, X u R$. ROR $\alpha$ binds to E2F1 to inhibit cell proliferation and regulate mammary gland branching morphogenesis. Mol Cell Biol 2014;34:3066-3075.

292. Purwar R, Schlapbach C, Xiao S, et al. Robust tumor immunity to melanoma mediated by interleukin-9-producing $T$ cells. Nat Med 2012;18:1248-1253.

293. Ivanov II, McKenzie BS, Zhou L, et al. The orphan nuclear receptor RORyt directs the differentiation program of proinflammatory IL-17+ T helper cells. Cell 2006;126:1121-1133.
294. Yang XO, Pappu BP, Nurieva R, et al. T helper 17 lineage differentiation is programmed by orphan nuclear receptors $\mathrm{ROR} \alpha$ and $\mathrm{ROR} \gamma$. Immunity 2008;28:29-39.

295. Rutz S, Ouyang W. The Itch to degrade RORyt. Nat Immunol 2016;17: 898-900.

296. Schmitt E, Bopp T. Amazing IL-9: revealing a new function for an 'old' cytokine. J Clin Invest 2012;122:3857-3859.

297. Bikle DD. Vitamin D: an ancient hormone. Exp Dermatol 2011; 20:7-13.

298. Slominski AT, Brozyna A, Jozwicki W, et al. Vitamin D as an adjuvant in melanoma therapy. Melanoma Manag 2015;2:1-4.

299. Fang $S$, Sui $D$, Wang $Y$, et al. Association of vitamin $D$ levels with outcome in patients with melanoma after adjustment for C-reactive protein. J Clin Oncol 2016;34:1741-1747.

300. Gandini S, Francesco F, Johanson H, et al. Why vitamin D for cancer patients? Ecancermedicalscience 2009;3:160.

301. Saw RP, Armstrong BK, Mason RS, et al. Adjuvant therapy with high dose vitamin $D$ following primary treatment of melanoma at high risk of recurrence: a placebo controlled randomised phase II trial (ANZMTG 02.09 Mel-D). BMC Cancer 2014;14:780. 